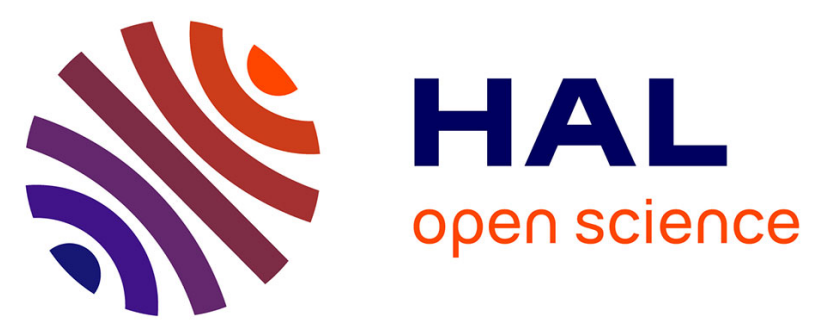

\title{
Studying activities that take place in speech interactions: a theoretical and methodological framework
}

Valérie Saint-Dizier de Almeida, Emmanuèle Auriac-Slusarczyk, Jean-Marc

Colletta, Antonietta Specogna, Jean-Pascal Simon, Gabriela Fiema, Christophe Luxembourger

\section{To cite this version:}

Valérie Saint-Dizier de Almeida, Emmanuèle Auriac-Slusarczyk, Jean-Marc Colletta, Antonietta Specogna, Jean-Pascal Simon, et al.. Studying activities that take place in speech interactions: a theoretical and methodological framework. International Journal of Qualitative Studies in Education, 2016, 29 (5), pp.686-713. 10.1080/09518398.2016.1145277 . hal-02320145

\section{HAL Id: hal-02320145 \\ https://hal.science/hal-02320145}

Submitted on 18 Oct 2019

HAL is a multi-disciplinary open access archive for the deposit and dissemination of scientific research documents, whether they are published or not. The documents may come from teaching and research institutions in France or abroad, or from public or private research centers.
L'archive ouverte pluridisciplinaire HAL, est destinée au dépôt et à la diffusion de documents scientifiques de niveau recherche, publiés ou non, émanant des établissements d'enseignement et de recherche français ou étrangers, des laboratoires publics ou privés. 


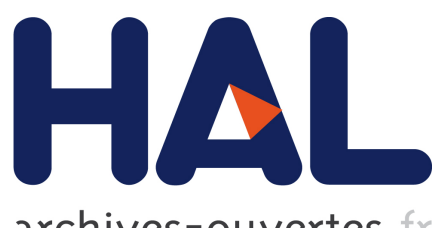

archives-ouvertes

\title{
Studying activities that take place in speech interactions: a theoretical and methodological framework
}

\author{
Emmanuèle Auriac-Slusarczyk, Valérie Saint-Dizier de Almeida, Jean-Marc \\ Colletta, Emmanuelle Auriac-Slusarczyk, Antonietta Specogna, Jean-Pascal \\ Simon, Gabriela Fiema, Christophe Luxembourger
}

\section{To cite this version:}

Emmanuèle Auriac-Slusarczyk, Valérie Saint-Dizier de Almeida, Jean-Marc Colletta, Emmanuelle Auriac-Slusarczyk, Antonietta Specogna, et al.. Studying activities that take place in speech interactions: a theoretical and methodological framework. International Journal of Qualitative Studies in Education, Taylor \& Francis (Routledge), 2016, 29 (5), pp.686-713. 10.1080/09518398.2016.1145277

. hal-02320145

\section{HAL Id: hal-02320145 \\ https://hal.archives-ouvertes.fr/hal-02320145}

Submitted on 18 Oct 2019

HAL is a multi-disciplinary open access archive for the deposit and dissemination of scientific research documents, whether they are published or not. The documents may come from teaching and research institutions in France or abroad, or from public or private research centers.
L'archive ouverte pluridisciplinaire HAL, est destinée au dépôt et à la diffusion de documents scientifiques de niveau recherche, publiés ou non, émanant des établissements d'enseignement et de recherche français ou étrangers, des laboratoires publics ou privés. 


\section{Studying activities that take place in speech interactions: a theoretical and methodological framework}

\section{Valérie Saint-Dizier de Almeida, Jean-Marc Colletta, Emmanuelle Auriac- Slusarczyk, Antonietta Specogna, Jean-Pascal Simon, Gabriela Fiema \& Christophe Luxembourger}

To cite this article: Valérie Saint-Dizier de Almeida, Jean-Marc Colletta, Emmanuelle Auriac-Slusarczyk, Antonietta Specogna, Jean-Pascal Simon, Gabriela Fiema \& Christophe Luxembourger (2016): Studying activities that take place in speech interactions: a theoretical and methodological framework, International Journal of Qualitative Studies in Education, DOI: $\underline{10.1080 / 09518398.2016 .1145277}$

To link to this article: http://dx.doi.org/10.1080/09518398.2016.1145277

\section{Published online: 19 Feb 2016.}

Submit your article to this journal ๘

\section{凹 Article views: 2}

View related articles

\section{View Crossmark data ־}




\title{
Studying activities that take place in speech interactions: a theoretical and methodological framework
}

\author{
Valérie Saint-Dizier de Almeida ${ }^{a}$, Jean-Marc Collettab ${ }^{b}$ Emmanuelle Auriac-Slusarczykc, \\ Antonietta Specogna ${ }^{a}$, Jean-Pascal Simon ${ }^{b}$, Gabriela Fiema ${ }^{c}$ and Christophe Luxembourger ${ }^{a}$ \\ aLaboratoire InterPsy, Université de Lorraine, Nancy, France; 'baboratoire Lidilem, Université de Grenoble, Grenoble, \\ France; ' Laboratoire ACTé, Clermont Université, Clermont-Ferrand, France
}

\begin{abstract}
The paper proposes a theoretical and methodological framework based on a pluralistic, concerted approach to the study of activities that take place in and through speech interactions. The framework has a general scope, applying to any collective activity taking form through language interactions. It contributes to a fuller understanding of the dynamics of activity and the emergence of the phenomena observed. The framework fits a constructivist and interactionist paradigm. It allows an approach to different dimensions of the activity: communicational, functional, discursive and interlocutory. The theories, models, concepts and methods chosen to address each of the dimensions are presented. From the study of a collaborative philosophical inquiry produced in the first year of a French primary school, we illustrate the use of the framework and show how it can be enriched according to the nature of the activity studied and researchers' aims.
\end{abstract}

\section{ARTICLE HISTORY}

Received 15 December 2013

Accepted 29 July 2015

\section{KEYWORDS}

Collective activity; communication; discourse analysis; reasoning; collaborative philosophical inquiry

\section{Introduction}

Our aim is to propose a framework to study the collective activities that take form in speech interactions (class work, business meetings, focus groups, etc.). The purpose of this framework is to describe this type of activity in all its complexity and from different viewpoints. The description is based solely on the study of a transcription of utterances produced during the activity. It is meant to provide a conceptual and methodological frame that will allow the activity to be considered from different angles. This preliminary work helps provide answers to questions such as: How and to what extent do individual utterances contribute to a collective construction? How are the speech productions interconnected? Which productions constitute premises for others and which are deductions from preceding interventions? How are the productions distributed among the interactants? How is the collective activity structured according to the speech productions? How does collective reasoning take shape?

The answers to these questions are of interest in the educational sciences where they may help achieve a fuller understanding of the acquisition processes taking place in collaborative contexts. Some researchers following Vygotsky have shown experimentally that interactions play a part in the acquisition process (Doise, Mugny, \& Perret-Clermont, 1975; Schubauer-Leoni, Bell, \& Grossen, 1989). Others have opted to focus on the behaviours produced in situations of interaction in order 
to study where the interactions emerge (e.g. Marro-Clément, Trognon, \& Perret-Clermont, 1999). However, the analysis often addresses only one or two dimensions of the activity (its cognitive dimension and/or its interlocutory dimension). Our aim here is to propose a methodology that allows several dimensions of the activity to be addressed. We expect that increasing the number of angles of approach to the activity will give us a clearer picture of all that is happening. To illustrate our approach, we have chosen a collaborative activity in a school classroom setting. This accordingly provides researchers in education with a discourse canvas close to usual classroom concerns: group work, teacher interactions, etc.

The dimensions considered here were chosen on a scientific basis. The overall approach to the activity is underpinned by the work of the Geneva group, for which all activities possess a functional structure (Roulet, Auchlin, Moeschler, Rubbattel, \& Schelling, 1985) that closely depends on the nature of the transaction (Kostulski \& Trognon, 1998), and by that of Flament (1965), which shows that collective activities that occur through discourse generate communication networks that tell us about the dynamics of the group activity. Lastly, a local study of the activity, focusing on linguistic phenomena such as repeats and shifts in meaning, identifies the distributed and/or co-constructed cognitive processes. This local investigation is based on the work of Trognon (1999), which shows that language interactions form the matrix for the communicability of cognitions.

The activity is addressed within a constructivist paradigm: a paradigm instigated by Mead (1934), developed in particular by the exponents of ethnomethodology and theorised, for example, by Suchman (1987) through situated action theory. In this paradigm, the performance of an action will depend on available cognitive resources, but above all on social and physical circumstances (Suchman, 1987) presented by the world as constructed here and now in and through actions already performed.

This paradigmatic stance gives rise to an interactionist approach to behaviour: understanding the dynamics of actions implies inquiry into the world under construction and so into previously performed actions. Understanding the dynamics of the activity will thus involve identifying the relations linking the actions.

Our investigation was based on a pluralistic, interdisciplinary, concerted study on the same single experience. The aim was to use the study of the language communications produced in their context to record the activity deployed, viewed from different angles. Our theoretical and methodological framework combined several disciplinary fields: developmental psychology, social psychology and linguistics. The theories, models, concepts and methods that compose our framework are designed to address different dimensions of an activity performed in and through language interactions. Thus, the focus of our work is this activity and its underlying processes.

Because the actions we are concerned with are materialised through the performance of language behaviour, we also need to draw on theories that explain the workings and dynamics of communication in our paradigmatic framework. This theoretical grounding is essential, firstly, because the specific rules governing communications impact, constrain and participate in the performance of the activity, and secondly because the analysis of the communication was to conduct calls upon methods that are underpinned by this theory.

The theory of communication we subscribe to is considered to be:

- Actional: we envision utterances not as phrases but as acts (Austin, 1970).

- Gestaltist: the communication cannot be reduced to the sum of alternating acts. The communication possesses an organisation, an architecture that is shaped and revealed as language production proceeds (Roulet et al., 1985).

- Dialogical: what is produced at a given time is an object, an event that will make sense through subsequent collective interpretation and exploitation (Trognon \& Brassac, 1992).

With this framework, the analyses we propose compared, for example, with the analysis of content and lexical analysis enable us to retain the interactional dimension of the spoken exchanges and so bring to light the dialogical processes and co-constructions (Saint-Dizier de Almeida \& Trognon, 2000). 


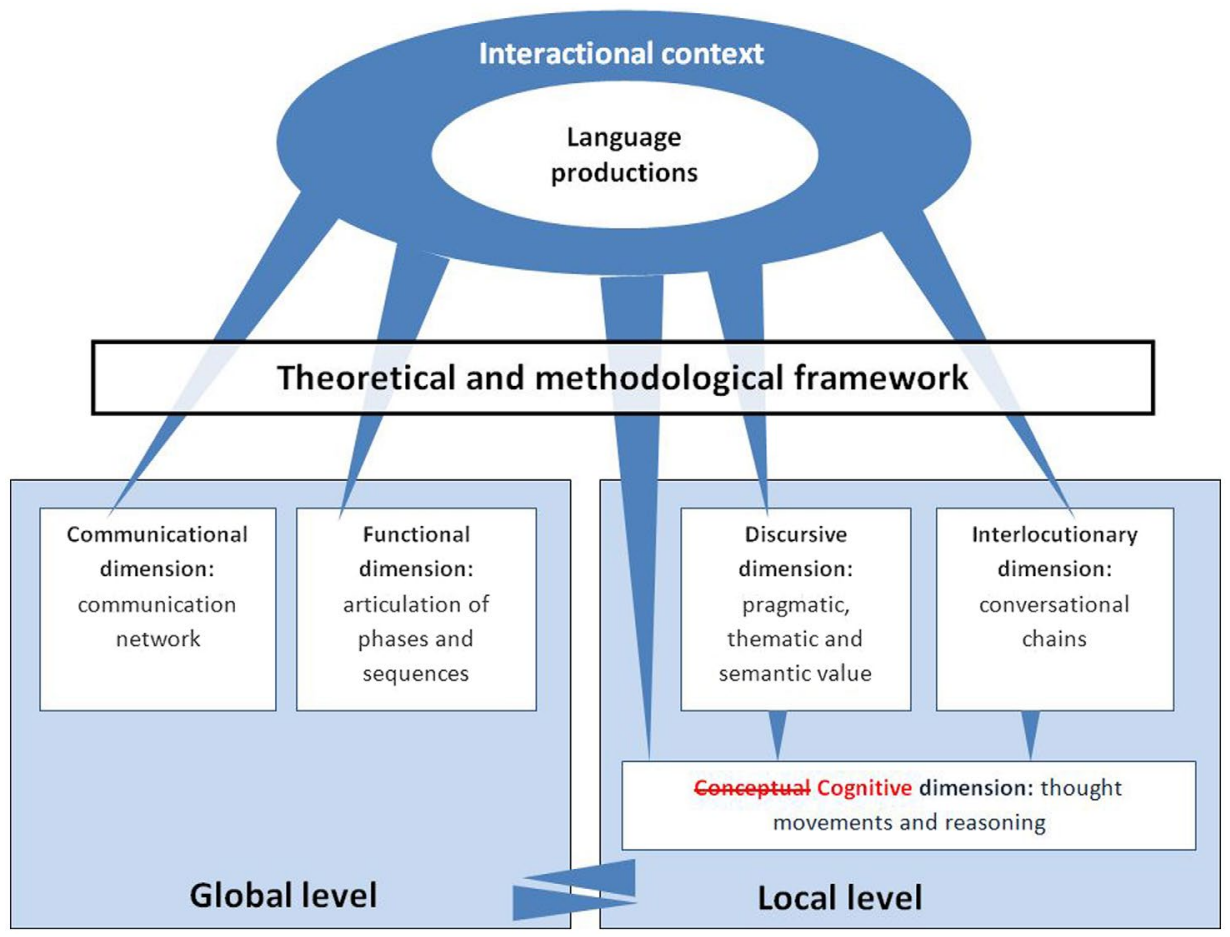

Figure 1. Depiction of the investigation process.

Notes: The cognitive dimension is not part of our generic framework, but we opted to include it to show that the results obtained in the other dimensions are necessary to describe the cognitive dimension.

In this theoretical and paradigmatic framework, and from whatever angle the activity is viewed (communicational, functional, discursive and interlocutory), the language behaviours are addressed through a sequential study of speech. This sequential study involves considering every language behaviour as a component of interactive sequences that are related to other components. The theories and methods selected for the construction of our framework thus read this interactionist dimension of the activity. The framework has a general scope insofar as it has been shown that the models and methods specific to each dimension can be applied to all collective language interactions: Flament (1965) for communication networks (communicational dimension), Trognon and Brassac (1992) through interlocutory logic (interlocutory dimension), François $(1990,1993)$ for concepts and linguistic methods (discursive dimension) and Roulet et al. (1985) for functional discourse architecture (functional dimension).

In this paper, we illustrate the use of our framework from the analysis of a collaborative philosophical inquiry (CPI). We show from this illustration that our framework, which is of general scope, can be extended according to the nature of the activity studied and researchers' aims: in our instance, to take into account the nature of the activity (activity produced in a classroom) and to meet one of our objectives (identify thought movements shown to characterise CPI) (Cappeau \& Auriac-slusarczyk, 2013; Daniel \& Auriac, 2011), we added the concept of "conversational loop" (CL) adapted for the study of classroom interactions (Specogna, 2013); to describe thought movements, we used the concepts and methods developed by Fiema (2014) to study the cognitive dimension of activities in CPI.

First, we present our theoretical and methodological framework, which is designed to be generic and must be applicable whatever the collective activity to be studied. In the Methods section, we first describe the activity used (a CPI) to exemplify our framework, and second how the data we use were collected and transcribed. We also state what additions were made to the framework. Thirdly, we present 
the results, which although are based on the data collected, reach beyond the simple CPI. Lastly, we discuss the results obtained, which demonstrate the advantages of a pluralistic approach.

\section{Framework}

Our aim was to describe a complex activity involving numerous actors that takes place in and through a collective speech activity in a dialogical discussion format as described and analysed by specialists in communicative interaction (Bange, 1992; Roulet, 1999).

For our study, we give emphasis to an interactionalistic, dialogical approach, where all productions are appraised with reference to the context in which they appear, and to their sequential pattern. Our postulate is that the identification of reasoning generated during an activity involving several speakers is possible only by studying the activity in all its dynamic complexity, and by considering it from different viewpoints. The method we propose thus begins with observable effects enriched by their interactional context, and aims to investigate different facets of the activity, as shown in Figure 1.

The activity was investigated from different viewpoints and in different perspectives (Figure 1). It was approached at a global level, centred on its communicational and functional dimension. Our approach to the communicational dimension consisted in studying the distribution of speaking turns (STs) and identifying the type of network deployed. Investigating the functional dimension involved identifying the key phases and sequences of the discussion and their articulation. This first approach provided a glimpse of the overall activity. It also supplied information to contextualise phenomena studied on the basis of a more local approach to discourse. At a more local level, the productions were approached in their discursive dimension as semiotic tools, or more precisely as "acted speech events", to which we could linguistically assign a pragmatic aim, a thematic content and semantic properties. The productions were also studied in their interlocutory dimension. The study, which uses a dialogical approach to discourse, focused on conversational chains, and aimed to identify the resources exploited by the protagonists, and discern to what extent the discourse was co-constructed. The study of the productions, supported by these two forms of investigation (discursive and interlocutory), made it possible to record the cognitive dimension of the activity. Emphasis was placed on the reasoning that takes shape in the discussion, with its semantic colour and its interlocutory properties. Our investigation set out to record the thought movements that could be deduced from an analysis of speech interactions.

\section{Communicational dimension: communication network}

This study identified in particular the type of communication network deployed. This consisted in studying how the speech productions were distributed over the class. This study made it possible to describe the participative setting characteristic of this type of interaction. The participative setting designates the

interlocutory roles actualised during an interaction (...): who was the speaker at time t during the interaction, and who was the interlocutor? Who became the speaker at time $t_{1}$ ? Did all the participants actively participate in the exchanges? Did any parallel interactions occur? (Colletta, 2004, 27 our translation)

This investigation was underpinned by the formalisations and schemes used in the 1950s and 1960s in social psychology for the study of communication networks: for a synthesis, see Flament (1965).

\section{Functional dimension of the activity: articulation of phases and sequences}

The study of the functional dimension of the activity consisted in identifying the phases and sequences that reflected the process of resolution in its chronological dimension. This investigation was based on the thesis whereby communication possesses an organisation, an architecture that is shaped by ongoing speech productions (Kostulski \& Trognon, 1998; Trognon \& Saint-Dizier, 1999), and this architecture contains, in particular, operating components: it accounts for the different time points during the process of resolution and their articulation (De Almeida \& Saint-Dizier De Almeida, 1998; Trognon, 
Saint-Dizier de Almeida, \& Grossen, 1999). These macrostructures take shape discursively as a succession of components connected linearly or hierarchically to others. To describe this architecture, we need a terminology that will take into account units at different levels. Based, in particular, on the Geneva school model (Roulet et al., 1985), which additionally provides the means to represent this type of structure spatially, and the work of Kerbrat-Orecchioni (Kerbrat-Orecchioni, 1990), we used the following rank units. We list them starting with the largest.

- Interaction. This denotes the discussion as a whole. It starts at the first utterance and ends at the last one.

- Phase. This unit can comprise one or several subunits (e.g. intervention, exchange and sequence: these will be defined later on) connected by a high degree of operational coherence. For example, a discussion between two pupils wanting to solve a problem in primary school might form the following succession of phases: an opening phase, a phase in which the facts of the problem are appropriated, a phase in which proposals for solving the problem are made, a phase for the transcription of the results and a closing phase (Trognon et al., 1999).

- Sequence. This unit comprises several subunits (intervention and exchange) "connected by a high degree of semantic and/or pragmatic coherence" (Kerbrat-Orecchioni, 1990, 218, our translation). Taking the previous example, the transcription phase can comprise several sequences: one to designate the pupil who is going to do the transcription, another during which the content to be written down is dictated, another to resolve a referential ambiguity, etc. The sequences are noted relative to the phase in which they occur.

- Exchange. This is the smallest unit of dialogue (it implies at least two speakers). "The constituents of the exchange are interventions linked by illocutionary relations" (Moeschler, 1985, 191, our translation). For example, one pupil asks another if he/she agrees to write the transcription; the other consents.

- Intervention. This is the largest monologic unit (produced by a single speaker). In the above example, the pupil asks the other if he/she agrees. His/her intervention may be composed of one single speech act. For example, an intervention defending his/her position will be composed of at least two distinct speech acts, one expressing his/her position, the other offering an argument.

\section{Discursive dimension: pragmatic, thematic and semantic values of verbalisations}

To characterise the speech events transcribed as regards their thematic content and their semantic properties, we refer essentially to François (1993) for an approach to oral expression, focusing on its interactive construction, and its often unfinished aspect, while still revealing the dynamics of thought, stance and intersubjectivity that traverse the dialogue. The utility of this approach is that it draws the analyst's attention to differences in wording, and to the effect of these differences on the child's discourse, as we will see through some of our examples.

A theory of argumentation is additionally necessary to identify and analyse the utterances that express an argumentative stance. Here, our frame of reference was that of Golder (1996), who lays emphasis on a psycholinguistic and pragmatic approach to argumentation, highlighting language operations oriented towards their effects: advancing a thesis or discursive position, supporting it by producing one or more arguments by an operation of "justification" and integrating the points of view of others or that of the defendant (Plantin, 1990) by the dialogical operation of "negotiation".

In this approach, support is the crucial operation: there is no argumentation without justification of a thesis by at least one argument. However, in children, as noted long ago by Piaget (1923), justification does not always proceed from reasoning. In a study of the explanations produced by children aged 6-11 years justifying a stance (Colletta, 2004), we identified three prototypical forms: (i) an explanation that involves reasoning, identifiable from the presence of networks of logical and argumentative connectors, (ii) an explanation based on hearsay or personal experience, recognisable by the non-generic 
character of the information and the presence of introductive formulae such as "What I see is ...", "For example, ..." and (iii) an explanation that expresses common knowledge, and relies on stereotypes.

\section{Interlocutory dimension: conversational chains}

The aim was to study how and to what extent individual utterances contributed to a collective construction. This was done by identifying how the productions were interconnected. Did some constitute premises for others? Or were they deductions from preceding interventions? Our analysis consisted in identifying the components underlying the production of an utterance: we identified the resources used by a speaker, and determined whether they took into account and built on preceding utterances, and if so how. This study of a corpus relies on a pragmatic and dialogical approach to speech productions. The analysis is based (i) on interlocutory analysis (Saint-Dizier de Almeida \& Agnoletti, 2010; Spigolon \& Specogna, 2000; Trognon \& Batt, 2003; Trognon \& Brassac, 1992; Trognon \& Kostulski, 1996) and (ii) hierarchical analysis of speech exchange (Roulet et al., 1985). In interlocutory logic, i.e. in a dialogical version of speech act theory, whatever the type of initiating act proffered, satisfaction depends on the interlocutors and not on the correspondence between what is said and a state of the world. Thus, "the interlocutor of the second phase of the interaction realises the conditions for the satisfaction of an assertive act if and only if he appropriates that satisfaction, i.e. holds the propositional content true" (Trognon, 1993, p. 100). The truth of the initiating act is assumed "by default", i.e. until proved false. Hence, the meaning belongs neither to the speaker nor to the auditor: it is a product that emerges jointly from both, i.e. from their relation.

Interlocutory analysis and hierarchical analysis of conversation show how utterances are structured, and how they contribute to the collective construction, by explicitating the conversational chain of utterances and their linkages. More explicitly, the analysis consists in relating an act produced to the act that responds to it in order to determine whether or not the responding speaker satisfies, in all or in part, the initial utterance.

\section{Methods}

\section{Data}

To exemplify our framework, we used a $\mathrm{CPI}^{1}$ produced during a session held with young pupils (6-7 years; see below). $\mathrm{CPI}^{2}$ is a school activity in which a teacher holds a class discussion on an issue relevant to the human condition, where the adult encourages the pupils to conceptualise at their level. The teacher generally acts as a moderator so that a field of collective reasoning opens among the pupils. The humanistic orientation of the CPI leads the pupils to address themes that have no single solution, and indeed allow for possible divergence (moral, ethical or cultural). Typical questions dealt with might be: Is life lent or given? What is the use of sharing? What is a friend? What does being free mean? Should we always tell the truth?, etc. In this class, the pupils were asked to debate orally in response to a question they themselves had defined in a previous class. The question was: "What use is sharing?" In CPI, the protagonists proffer possibilities, advance hypotheses, present arguments, explicitate, illustrate and form abstractions. One major process in play is bringing participants into adversarial debate, and seeing how they "get out" of this situation.

\section{State of research on CPI}

Most of the research on CPI has studied the impact of this type of discussion on critical thinking, and on the skills assumed to be required for this type of activity, such as decentring, argumentation, conceptualisation, abstraction and creativity (Auriac-Peyronnet \& Daniel, 2002; Daniel, 2005; Tozzi, 2007; Auriac-Slusarczyk \& Daniel, 2009; Auriac, 2007). CPI has also been shown to have a positive impact on certain cognitive and academic capacities that are less directly involved: ability to learn and to reason (Higgins, Hall, Baumfield, \& Moseley, 2005; Mortier, 2005; Topping \& Trickey, 2007), performance in 
mathematics and reading and overall educational attainment (Higgins et al., 2005). Socially, it has been observed that CPI leads pupils to cooperate more (Williams, 1993), and to develop moral values such as honesty and respect for others (Australian MCEETYA programme, 2008). The practice of CPI may strengthen pupils' critical faculties (Auriac-Slusarczyk, Adami, \& Daniel, 2011).

In recent years, research has shifted its focus away from testing towards an analysis of the productions obtained through CPI. Through case studies, researchers have sought to explicitate the process by which reflexivity develops (Tozzi, 2007), and more generally to characterise the thought movements that are specific to the philosophical nature of the discussions held (Cappeau \& Auriac-slusarczyk, 2013; Daniel \& Auriac, 2011).

This type of conversational context is conducive to the emergence of thought movements and reasoning patterns characteristic of CPI. Surprising though this may seem, the age of the pupils is not an important consideration from our point of view. Pupils can make use of the CPI to deploy their reasoning irrespective of their level of educational attainment.

\section{The CPI used}

The CPI was taken from a corpus of several CPIs collected in the region of Nantes (France) in 2010 from children in primary school (aged 7-11 years) and junior secondary school (age 12-15 years) who had already practiced CPIs for at least 4 months, i.e. who were able to produce collective reasoning. This collection was part of a programme designed to extend work carried out in education science (Auguet, 2003; Caillier, 2001; Connac, 2002, 2004; Tozzi, 2007; Usclat, 2008) and in linguistics (Rispail, 2007), which set out to study this reasoning from verbal material, instead of solely from the aims of pedagogical practice (Daniel, 1997; Lalanne, 2002; Lipman, 1995) or from the argumentative dimension contained a priori in such practice (Tozzi, 2007).

In our study, the CPI used was not selected for any reason other than because it happened to be the first one to be transcribed when the research group's interdisciplinary work was started. It was produced during a first year in a French primary school by a class of 23 pupils ( 14 girls and 9 boys). The fact that these children were young and, unlike older pupils, unskilled in certain reasoning options (e.g. deductive logic, knowledge support or cognitive decentring) did not hinder the study of the reasoning process. On the contrary, the apparent simplicity of the exchanges was belied by the analysis we performed (see results), which thus empirically validated this choice of young pupils. A study of CPI with older or better trained pupils would doubtlessly have revealed different logical chains.

The teacher who animated the CPI had undergone training in the principles of regulation of a CPI. This training was in two phases. In the first phase, the traditional supports of Lipman (1995) used to elicit philosophical issues from the pupils themselves were presented. In the second phase, recommendations for managing discussions in the CPI were produced, such as favouring curiosity, looking more closely at conceptually loaded words, reword if possible, making sure not to thwart discussion, giving free rein to STs, making three mini-recaps during the discussion, and not being judgemental. In practice, the teacher, upstream of each CPI, set in place a session devoted to the production by the pupils of several philosophical questions (generally at least one per pupil) using children's books as a support and to trigger questioning. At the end of the session, a question was chosen democratically by the class (e.g. Why are there poor people? What is a leader for? Why do people quarrel? Is it good to make fun?). The question chosen then served to launch a session devoted to the $\mathrm{CPI}$, the subject of our investigation. During the school year concerned, the teacher conducted 24 CPIs. The CPI studied was the $23 \mathrm{rd}$.

During the discussion, the children were seated in a circle, each in front of their table. The teacher was inside the circle with the pupils.

\section{Transcription and annotation of data}

The analyst had to process pre-recorded speech data. This work involves two tasks, namely: transcription and annotation. 
The transcription of the corpus collected for this study was orthographic, as shown by the examples given below, and intended to describe interactive speech, with its specific patterns of enunciation (false starts, repeats and rewording and hesitations), its pauses and its silences and overlapping of utterances from different speakers. For this purpose, we adapted the transcription conventions proposed by our Belgian colleagues in the VALIBEL team (http://valibel.fltr.ucl.ac.be/).

The annotation of the utterances of the teacher and the pupils was based on a unit well known to pragmaticians: the speech act. Why did we opt for this unit rather than the sentence or the utterance?

All the specialists of spoken French agree that the written sentence has no equivalent in the spoken language, except when a text is read out, when the speaker will endeavour to use prosody to express the written punctuation and phrasal segmentation. It would be more accurate to say that an oral message is structured by utterances, although this term has been contested, some preferring "clause", "period" or "proposition" (Adam, 1999; Berrendonner, 1990). But why speech act rather than ST or intervention (Roulet et al., 1985), a unit that is much easier to identify than the speech act?

The reason for our choice stems from the specific features of CPI. First, in CPI, like in other categories of oral dialogue, the teacher's speech is often pluri-intentional and polyphonic: in the same ST, the teacher can validate a pupil's response, ask the whole class a question and admonish another pupil, thereby executing several acts and activating several exchanges. Second, CPI elicits argumentative speech, which is based on the articulation of several assertive acts (a minima, following Golder, 1996, the statement of a thesis and the statement of at least one argument in support of that thesis). For both these reasons, the annotation of the teacher's and the pupils' speech in CPI must first of all be an annotation by act.

Our categorisation of the speech acts in the corpus is based on the typology of Searle (1982). This typology provides a characterisation of the illocutory act produced via each language behaviour (assertive, directive, commissive, expressive and declaration). It was refined for the study of directive acts so as to distinguish "requests to speak" from "requests to do". This step, by which we determine the illocutory functions, then allows interlocutory analyses to be undertaken, which take into account sequential phenomena characteristic of dialogue, whereby an assertion can open up an exchange between two speakers (A asserts something, to which B prepares to respond), or conversely close it (e.g. when the responding assertion of $B$ supplies the information awaited by $A$ ). This step also enables us to study the linguistic dimension of the discourse (whether the assertive act expresses an idea, an argument, an illustration, etc.).

Hence, our typology is also supported by conversational analysis and Geneva school pragmatics (Colletta, 2013; Kerbrat-Orecchioni, 1990; Roulet et al., 1985).

We add that certain dimensions of the activity will lead us to use other units of analysis, which we will describe when relevant.

\section{Study of data: enrichment of the framework}

\section{Communicational dimension}

The corpus was produced in a classroom: this led us to use the concept of the " $\mathrm{CL}$ " as developed by Specogna (2013) for the study of classroom interactions. A CL is a sequence produced by two speakers that forms part of a polylogue. A CL comprises several STs. An ST starts when a speaker speaks, and ends when a second speaker speaks in turn (Kerbrat-Orecchioni, 1990). A CL opens when a speaker addresses a particular interlocutor, and closes when the interaction switches to speakers other than those involved in the CL. CLs are conversational structures that appear fairly regularly in school activities (Specogna, 2013). The aim was to construct a representation of each CPI indicating who was speaking and when, the length of each $\mathrm{CL}$, and by whom it was started.

\section{Cognitive dimension}

Our approach to reasoning requires a conceptual parenthesis. Like Lipman, we are interested in reasonableness. For Lipman, the term reasonableness ${ }^{3}$ supersedes that of reasoning (Lipman, 1995, 
2005). The main concern for Lipman, and for those following him, was to emphasise the dynamics of reasoning, i.e. the activity at the core of reasoning, rather than the result. Reasonableness denotes the process at work that links reasoning to argumentation, in the sense that the process tends towards truth (Lipman, 2005). It is this tension, this thought movement, that is important, as in François (1980). For the latter, argumentation is based on a heterogeneous approach where the linking up of ideas reveals the tension of real/true, which psychologists specialised in reasoning have already described (Oléron, 1977).

For reasoning to be brought into play, neither a strong interest in the subject concerned nor a smooth flow of dialogue is sufficient (François, 1980). There can be a confrontation on a shared theme supported by a discourse or by experience, but the interlocutors may remain parallel and never meet. A qualitative degree of linking in the exchanges is necessary. Repeats, rewording and additions to a thematic series of aspects or viewpoints are a minimal condition without which no philosophical argument is possible. The interlocutor's discourse must be integrated in the speaker's.

All discourse is bounded - in particular through the constraints of the institutional setting and the context of interaction (Vion, 1992) - in referential fields: we talk of or about something. Words can be used (i) purely referentially, (ii) as a shared referent, (iii) to illustrate an idea or (iv) as a conceptual basis for reasoning. The shift in use of a word through these different levels - pure referent, shared referent, idea and concept - proceeds through successive stages. This conceptual framework was tested on 19 CPIs (Fiema, 2014).

At this point, it is apposite to define some of the terms we use to describe the thought movements and reasoning that occur during CPI - these definitions are from Fiema (2014).

- A referent is the representation of an experience, something in the world that is referred to by a linguistic sign. A given referent can refer to different representations. These representations will be brought together during the interlocution.

- A shared referent arises from explicit sharing (repeat or synonym), which sets, over a certain number of STs, the referential basis for the collectively produced discourse.

- An idea is an attempt to carry the discussion forward starting from a shared referent. The ideas that are produced will form the material from which the referent will give rise to a concept.

- A stage is materialised through an idea that influences how the reasoning is collectively constructed. The idea is taken up several times in the discussion and validated or invalidated by the interlocutors.

- A concept is the result of the collective construction of the meaning of a shared referent through the production of ideas.

- An instance of collective reasoning is a conclusive piece of reasoning that delimits a conceptual field considered as having reached a sufficient degree of completion. It is characterised by a shared attempt to advance the definition of the shared referent through the interplay of ideas, and to tend towards truth. Thus, the speech acts that occur, in addition to their informative purpose, serve to validate or to invalidate, to support or to challenge.

Collective reasoning is constructed around a concept; it exploits ideas forming a chain of discursive entities that are extensions of the starting referent. It comprises argumentation and abstract reasoning. It is characterised by lexical shifts, repeated lexical items and new lexical items. It is a collective discursive construction that corresponds to a process that can translate "highs" and "lows" in the reasoning. A "high" is when reasoning is in action, and brings out ideas and conceptualisation. A "low" is when the philosophical reasoning comes to an end.

The aim was thus to describe, understand and record the collective constructs that appear in a CPI. To delimit these instances of collective reasoning, we use the term step: a step is a discursive period of ranging length during which a specific referent is collectively produced, explored and enriched. Interlocutory logic (Trognon, 1999) is used to describe these collective thought movements. 


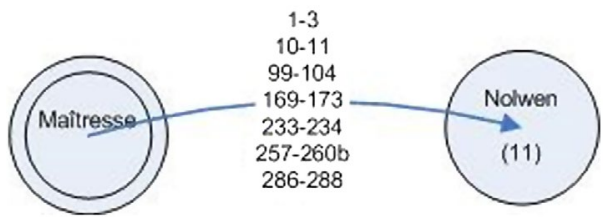

Figure 2. Depiction of exchanges between two interlocutors (from Specogna, 2013). Note: Teacher ("maîtresse") and students.

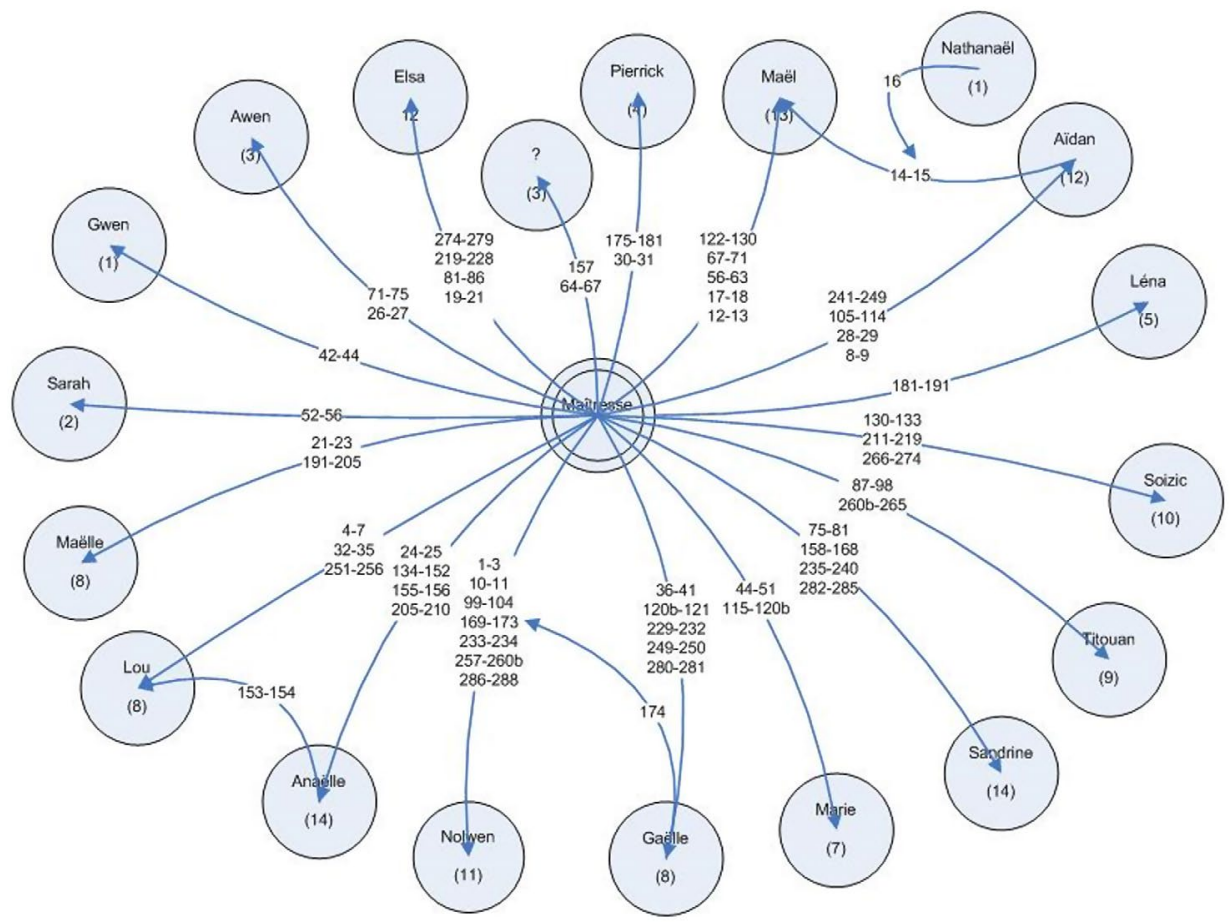

Figure 3. Distribution of STs in the discussion studied (from Specogna, 2013).

Note: Teacher ("maîtresse") and students; a question mark means the pupil was not identified.

\section{Results}

Our results are presented in turn for each dimension studied: communicational, functional, discursive, interlocutory and finally cognitive, although these are all interdependent.

\section{Communicational dimension: communication network}

In the representation, we use to describe the communication network, each member of the class forms a node (Flament, 1965), which we represent by a circle; each is labelled with the member's name. The exchanges $(\mathrm{CL})$ among the members are materialised by lines connecting the nodes involved.

The point where a $\mathrm{CL}$ started is marked by an arrow.

The place of each $\mathrm{CL}$ in the overall exchange is indicated by the ST number opening the $\mathrm{CL}$, and that closing it. This indication allows (i) the statement of the number of interventions comprising each CL and (ii) the positioning of the CLs in the overall discussion. Here is an example:

In Figure 2, the two participants involved are the teacher and Nolwen. The line joining the two nodes materialises the exchange between them. Between the two nodes, we have listed the CLs in which the 
two interlocutors have participated. The arrow pointing towards Nolwen means that all seven CLs were started by an intervention of the teacher directed to Nolwen. In Nolwen's node is shown the number of interventions she has produced: here 11 interventions. For each $\mathrm{CL}$, we also state the number of the interventions that opened it, and the number of the interventions that closed it. This indication records the length of each CL. For example, "1-3" means that the CL comprised three interventions.

Figure 3 depicts the distribution of the communications observed in the CPI.

In all, 19 pupils out of 23 participated in the discussion. We can see (Figure 1) that 7 pupils were particularly active in the discussion (they participated in more than $4 \mathrm{CLs}$ ), and 12 pupils participated less. The direction of the CLs shows that the teacher initiated all but three of them: Anaëlle and Lou (153-154), and Aïdan responding to Maël 13 (14-15), eliciting a response from Nathanaël (16).

The teacher thus formed the node of the communication network through which practically all the exchanges passed. We thus have a centralised network, as shown in Figure 1. The type of network obtained for the discussion studied shows us that the status of the participants (teacher/pupil) constrains the participative framework. In this context, and in the management of turn-taking, the teacher's role is to allot STs, and the pupils' role is to ask for them and take them when the teacher permits. When a pupil takes a ST, there ensues a teacher-pupil exchange $(\mathrm{a} \mathrm{CL})$ of ranging length.

\section{Functional dimension: articulation of phases and sequences}

The analysis revealed different operating phases. One comprised several sequences (phase 2 in Figure 4). The different phases and sequences, and their articulation, are set out in Figure 4.

We can see that each of the phases was started by the teacher in an intervention addressed to the class. The address of the intervention was generally marked by the use of the personal pronoun "you".

The interaction (Figure 4) comprised four phases: P1 formulation of the task, P2 production, P3 recapitulation and $\mathrm{P} 4$ closure. These phases reflect a conventional organisation of task resolution (Kostulski \& Trognon, 1998; Trognon et al., 1999). Phase 2, which is more complex, comprised three sequences corresponding to a progression in the production (P2.S1, P2.S2 and P2.S3); these last conditioned the recapitulation phase (P3) as shown by the hierarchical structure.

This scheme also tells us about the process of collective thought deployed. We can see that P2.S1 offered some answers to the questions asked in P1; P2.S2 and P2.S3 essentially reported personal experience that could give rise to argumentative productions. More precisely, the examples in P2.S2 illustrate sharing; the examples produced in P.2.S3 illustrate sharing, non-sharing and difficulties in sharing.

\section{Discursive dimension: pragmatic, thematic and semantic values of speech events}

We then looked at the content of these STs, beginning with their performative dimension: What did the participants "do" when they spoke? What speech acts did they perform? As indeed we might expect, given the type of conversation we are concerned with here (CPI) (bearing in mind that it took place in a first-year primary school class), most of the pupils' utterances were not argumentative. Many STs, unless they were merely factual answers to a question from the teacher, reported personal experience and so were narrative. The analysis of the corpus reveals a complete continuum from the anecdote, a pure account of an event with no commentary, to a stance supported by reasoning, taken up or not by the teacher or another pupil. Below are some examples showing the types of participation in the discussion we could find.

\section{Anecdote}

Several versions of the question (usefulness of sharing, whether or not we should share, whether or not we want to share, etc.) generated simple reported examples of sharing episodes with no commentary. In some cases, the pupil's utterances were simply validated by the teacher, who then solicited another pupil. In other cases, the teacher questioned the class starting from an event, but this questioning failed 
Phase 1. Formulation of the task

\author{
Sequence P1.S1: Communication of the question \\ (What use is sharing?) \\ and elicitation for production \\ (I1(teacher)-I3b(teacher))
}

Phase 2. Production

Sequence P2.S1: Arguments justifying why it is good to share and/or counterfactual examples (8) (13c(teacher)-I31)

Sequence P2.S2: Personal experience illustrating sharing and/or arguments (5) (I32(teacher)-I54a(teacher))

Sequence P2.S3: Arguments justifying not sharing (2), difficulties (2), sharing (1), experience illustrating not sharing (3), difficulties in sharing (5), sharing (11)

(I54b(teacher)-I269)

Phase 3. Recapitulation

Sequence P3.S1: A new reason (1), personal experience not yet mentioned (2), reasons justifying why it is good to share already given (1) I270(teacher)-I292a(teacher)

Phase 4. Closure (1292b(teacher))

Figure 4. Articulation of phases and sequences.

Notes: The number of CLs produced in each of the sequences is stated in brackets. We also state the number of the intervention by which a phase or a sequence started, and the number of the intervention that closed it. When these interventions were produced by the teacher, this is stated in brackets. For example, 1270 (teacher) was the 270th intervention, and was produced by the teacher. "I54b(teacher)-1292(teacher)" means that the phase was stated by the teacher in intervention I54, and was closed by the teacher in the 292nd intervention of the interaction.

to detach the pupil from the event. The following excerpt illustrates this attachment to anecdote or event, with the teacher's "and so?" signalling an unsuccessful attempt to bring the discussion back to the initial point (should we or should we not share?): 
91. Titouan: sometimes when it was my cousin // like // like he doesn't much want to share with his cousins

92. Teacher: and so?

93. Titouan: like // uh uh // after uh he uh my cousin he went with him // but he wanted // uh my brother uh // to go for the trampoline

\section{Problematised narration}

When a link was made between relating an event and the question targeted in the exchange, it was often the teacher who prompted the pupil on the subject (but what did you get out of sharing [...] that's the question) and enunciated this link (so the point was it made you happy):

253. Lou: well:: it was it's quite nice 'cos like that // after we talk and we talk // and:: // well we're happy and uh //\{mumble\} she lent it me'cos // like one day uh //\{mumble\} I went and stayed at her house // and then uh how // she did lend me a game // and \{inaudible\} they changed the bed // uh I slept right on the mattress // so // after XXX slept // in her bed // so after around uh dunno what time // uh // I was in the bed // and XXX got on in on the mattress

254. Teacher: but what did you get out of sharing, Lou, that's the question xxx

255. Lou: well \{inaudible\}

256. Teacher: so I can see you shared lots of things but:: // what was the point of it all?

257. Lou: it was nice // and uh when uh we when I got home // I was I was happy

258. Teacher: you were happy // right so the point was it made you happy

We note that in this excerpt, at ST 253, the pupil had already tried to make a link between having shared something and the idea that this makes someone happy (it's quite nice 'cos like that // after we talk and we talk // and:: // well we're happy). A further degree of abstraction and generalisation would have meant drawing out a maxim: "sharing with other people makes you happy", but we can see that the teacher did not wish to go any further, and stayed anchored to the event (so the point was it made you happy). In other, less frequent, cases, the link between recalling an event and the aim of the discussion was made clearly explicit by the pupil, as in ST 233 below:

229. Gaëlle: when I went to Nolwen's birthday party // um, we took photos, and we filmed and // like she'd lent me her camera so we could:: // so we could [do/take] things with it

230. Teacher: and you were pleased she lent you her camera

231. Gaëlle: \{nods\}

232. Teacher: and Nolwen why did you lend her your camera, why didn't you keep it just for yourself? 233. Nolwen: 'cos // um, it was new and I wanted to show it // and then uh /// I wanted and then I lent it to her // 'cos // it was better // to lend it 'cos if not uh // if not \{inaudible\} don't know what to do so uh // I lent it and with my camera it was fun // so it's better to lend things 'cos like that we we get we:: play // it's more fun

From the recall of an event, the pupil took a stance (it's better to lend things) and argues ('cos like that we [... play //it's more fun), and explicitated the move from narration to argumentation using the connector "so", which marks here the transition between two worlds: that of experience and that of thought. But the transition often occurred in the opposite direction, with argumentation supported by testimony. 
Table 1. Rewording of problem F1 in the course of the discussion.

\begin{tabular}{|c|c|c|c|}
\hline Speech event & Wording & Operator & Category \\
\hline 12: Nolwen: what use is sharing & $\mathrm{F} 1$ & what use is & Usefulness \\
\hline $\begin{array}{l}\text { 14: Lou: it's good to share \#'cos how \# like that well a boy's:: sis- } \\
\text { ter:: well he / \# she's got the she's got half the pack of paper } \\
\text { and the other half of the pack of paper \# and:: [...] }\end{array}$ & F2 & it's good to & Axiological modality \\
\hline $\begin{array}{l}\text { I10: Nolwen: you've got to share 'cos \# after uh the others } \\
\text { they're our friendsand we're friends \# for example uh \# some } \\
\text { bring:: \# things to school toys \# and then the other [...] }\end{array}$ & F3 & you've got to & Deontic modality \\
\hline $\begin{array}{l}\text { I32: Teacher: what you mean is that you're saying all of you } \\
\text { that it's good to share uh you share all the time \# all the time } \\
\text { you're saying oh I share I'm really glad to share }\end{array}$ & F4 & all the time & Aspectual modality \\
\hline $\begin{array}{l}\text { 143: Marie: sometimes uh \# it's good to share 'cos \# some uh } \\
\text { like mm \# they want uh \# to dress up and then uh \# I don't } \\
\text { mind sharing }\end{array}$ & F5 & I don't mind & Volitional modality \\
\hline $\begin{array}{l}\text { 166: Teacher: no not always \# and why then \# why is it not } \\
\text { good to share sometimes }\end{array}$ & $\mathrm{F} 2^{\prime}$ & is it not good & Axiological modality \\
\hline $\begin{array}{l}\text { 173: Awen: in fact you can share 'cos it's x x \# and then some- } \\
\text { times when you don't really want to \# or else when you want } \\
\text { to you can share sometimes share or not }\end{array}$ & $F 3^{\prime}$ & you can & Deontic modality \\
\hline
\end{tabular}

\section{Argumentation supported by testimony}

Argumentation with support from the utterer's own experience was a recurrent pattern in the pupils' discourse:

197. Maëlle: it's good to share 'cos in fact // with my friend // in fact // uh I lent her some caram uh I gave her some carambars // but she wasn't in so well I gave'em to // to her daddy

Often, the pupil took support from a classmate's utterances and marked an agreement (or disagreement) with the point of view adopted. We then had an echo or "diaphonic" response (Roulet et al., 1985), illustrating the dialogical dimension of the exchanges:

135. Soizic: I agree with Nolwen and Marie // 'cos sharing // you share // too when you // / / brought // some sweets to school // I had I shared them

136. Teacher: and so?

137. Soizic: and then uh // \{inaudible\} // we played together and then we sh // we shared everything

\section{Argumentation supported by doxa}

Another recurrent figure was argumentation supported by discourse or opinion. We find an excellent example in the excerpt below:

98. Teacher: and do you think it's better to:: share your things or to keep them all for yourself

99. Titouan: that it's better to share

100. Teacher: why Erwan

101. Titouan: 'cos uh // uh // like that it's more polite and then uh // there's the others who want to be // friends with us all the time

At ST 101, to support his point of view (it's better to share), the pupil advanced two arguments (it's more polite, you get more friends) that were neither drawn from personal experience (which he did not relate here) nor used in reasoning. 


\section{Argumentation supported by reasoning}

Less often, we saw argumentation supported by reasoning, but given the children's young age, we often found attempts at or fragments of reasoning rather than conclusive reasoning. These attempts sometimes ended in:

- Tautology (reworded here by the teacher):

271. Soizic: it's good \{to share\} // and:: // also // it makes you learn

272. Teacher: it makes you learn?

273. Soizic: yes

274. Teacher: to learn what

275. Soizic: to share

276. Teacher: sharing makes you learn to share

277. Soizic: $\{$ nods $\} / /$ it $m$ it makes you learn to share

- Circular reasoning, based on an opposition as in the excerpt below, where the pupil opposed "sharing = polite" and "not sharing = not polite":

215. Soizic: it's good to share //'cos if not you // you're not // your not being polite // when [you] share // it's good // but when you don't share it's bad // when you share // you can share // you // you:: you're nice // and you're being polite // but when you don't share // you're not nice and you're not being polite

- Reasoning by contrast, as in the excerpt below, where a pupil used a temporal contrast "to start with / after":

109. Aïdan: how // uh well // it's good to // it's good to share'cos // sometimes like people // to start with they want // uh sometimes // in fact and like people they don't want to share to start with // and then uh when they haven't been sharing enough // and like after like they share with other people

The next part of the excerpt is instructive and shows that the teacher, faced with this tentative reflexivity, was able to bring the pupil to complete or carry on their reasoning:

110. Teacher: when they / haven't been sharing enough, but how do they go from:: // from when they don't share to when they do share why do they suddenly start sharing Enzo

111. Aïdan: um:: //'cos:: // there's people who think uh:: after uh that it's good to share

112. Teacher: why

113. Aïdan: 'cos:: you can make friends

114. Teacher: if not they're left on their own

115. Aïdan: yes

116. Teacher: when you don't share

117. Aïdan: $\mathrm{mm}$

The teacher first had the pupil extend her reasoning (ST 110 and 112), and then explicitated the underlying relations ("if not ..." in ST 114,"when ..." in ST 116) in an effort to support and dialogically construct a reasoned discourse which was still difficult for the pupil to manage alone. 
Lastly, in some pupils, we found an instance of conclusive, fully logical reasoning, as in the last excerpt below:

261. Nolwen: I didn't agree with Soizic // well 'cos how // uh it's better it's good to share right // but there's no use // it's uh // you're polite but sometimes you don't want to share // and you're polite all the same so you do [some/the] things uh // to be polite

262. Teacher: right so for you sharing means not being polite // [...]

Here, the pupil expressed her disagreement with a classmate's point of view using concession ("right") and counter-argument ("but").

Anecdotes taken up or not by the teacher, points of view more or less successfully argued by the pupils, utterances supported to varying degrees by the teacher: all these speech events were both the support for and the product of the reflexivity in play during the discussion. They also gave rise to shifts in meaning that are highly relevant to the identification of instances of collective reasoning.

In the present case, the initial question of the discussion: "what use is sharing?" constantly evolved with successive STs by the teacher and the pupils. Every time the problem was reworded, a new modality was launched: axiological, deontic, aspectual or volitional. Historically, the concept of modality was introduced in linguistics to take into account, inter alia, possible variations or patterns in the way an utterance is presented or enunciated: a fact can be presented by an utterer as certain or probable, possible or necessary, wanted or unwanted, positive or negative, etc. ${ }^{4}$ Table 1 presents the four main types of rewording that we could identify from the transcription of the participants' words, together with the indication of ST and the speech event during which they occurred.

As the teacher and the pupils conversed, we thus went from the usefulness of sharing (initial wording $\mathrm{F} 1$ to the issue of whether it is good (F2) or not $\left(\mathrm{F} 2^{\prime}\right)$, if you should share (F3) or if you can share (F3'), in what conditions (F4) and with what volition (F5).

Below are some examples of these shifts.

We can see the first one right at the start of the discussion, as illustrated in the following excerpt:

\section{Nolwen: what use is sharing}

3. Teacher: it's a question you've chosen // you must have things to say

[three pupils raise their hands]

4. Teacher: Cassandra

5. Lou: it's good to share 'cos 'cos how // like that well a boy's:: sister:: well he / \# she's got the she's got half the pack of paper and the other half of the pack of paper \# and:: when they've got a box uh for both of them with felt tips and crayons

6. Teacher: so why is it good to share then

This rewording of the question introduced a change in the point of view which switched from the utilitarian value: "the use of sharing is ..." to a value expressed in moral terms: "it's good / bad to share".

At ST 54, we saw the teacher rewording the question in quite a fundamental way:

54. Teacher: right // but it's good when:: so I'm going to give you an example I at the gate the other day // there was uh // there was a birthday in the school and so it was in some class I don't know which, but // there was a little boy who had two sweets and his grandma told him now give one to your sister you share, you've got two now you share // and the little boy said no no no // they're my sweets they're:: // they're for me // doesn't that ever happen to you to be like that do you always think it's good to share 


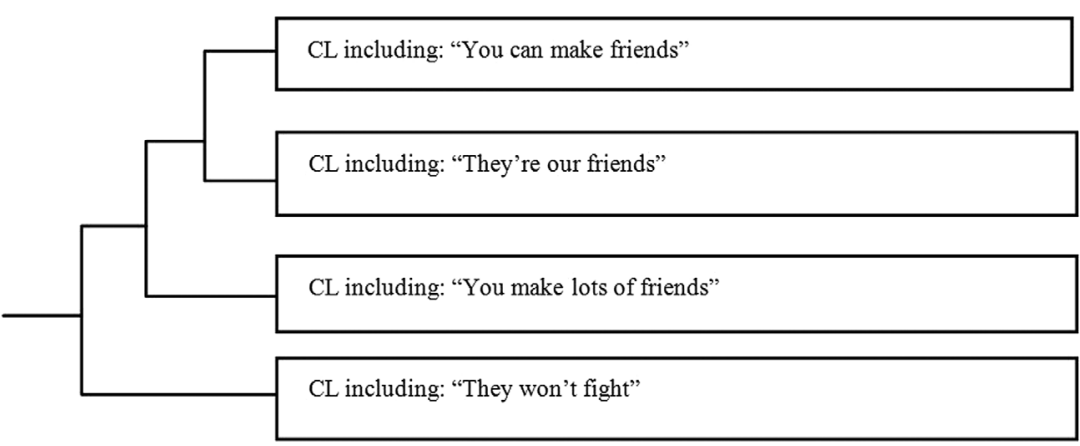

Figure 5. Hierarchical articulation of Cls.

Table 2. Occurrence of functions of teacher's responding interventions during P2.S1.

\begin{tabular}{lcccccc}
\hline & Make intelligible & \multicolumn{3}{c}{ Guide, assist, explore } & Total \\
\hline $\begin{array}{l}\text { Contribution: } \\
\text { clarify the } \\
\text { discourse }\end{array}$ & $\begin{array}{c}\text { Contribution: } \\
\text { ratification }\end{array}$ & $\begin{array}{c}\text { Request: for } \\
\text { further infor- } \\
\text { mation }\end{array}$ & $\begin{array}{c}\text { Request: } \\
\text { To prompt } \\
\text { exploration }\end{array}$ & $\begin{array}{c}\text { Request: } \\
\text { directing to- } \\
\text { wards a new } \\
\text { register }\end{array}$ & $\begin{array}{c}\text { Contribution: } \\
\text { submission } \\
\text { deduction }\end{array}$ \\
\hline 2 & 0 & 1 & 1 & 0 & 0 & 4
\end{tabular}

Here, the teacher took up the pupils' way of reasoning: "I'm going to give you an example", but she used this strategy to bring in a counter-example to cause the pupils to think about non-sharing situations. However, this intervention was not sufficient, and had to be reiterated:

64. Teacher: so // you're all telling me that it's good to share, but do you do it afterwards

A little further on, the teacher reworded her question after an intervention by a pupil who proposed a new sharing situation without clearly considering a non-sharing situation:

73. Awen: in fact you can share 'cos it's x x \# and then sometimes when you don't really want to \# or else when you want to you can share \{inaudible\} share or not

74. Teacher: sometimes you share or you don't it depends // and why do you not share sometimes and why do you share other times

Some 20 STs were needed to install this polarity sought by the teacher, but the pupils found it difficult to enter into this dual perspective.

These shifts in meaning were all possible traces of thought movements and reasoning that could emerge as the discussion proceeded, and which will be identified in the section titled'cognitive dimension'. But their chaining, and the alternation of acts that were more obviously narrative or by contrast strongly argumentative, helped first to signal transition, steps and key moments in the discussion taken into account by the overall analysis of the activity. 


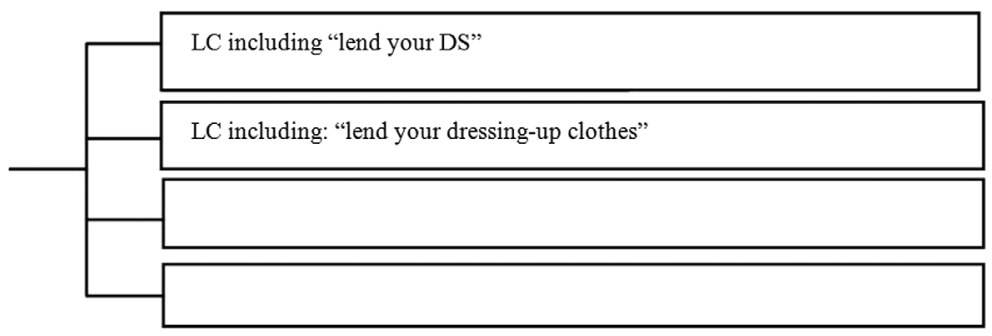

Figure 6. Linear articulation among CLs.

Table 3. Occurrence of functions of teacher's responding interventions during P2.S2 and P2.S3.

\begin{tabular}{lcccccc}
\hline & Make intelligible & & \multicolumn{3}{c}{ Guide, assist, explore } & Total \\
\cline { 1 - 1 } $\begin{array}{l}\text { Contribution: } \\
\text { clarify the } \\
\text { discourse }\end{array}$ & $\begin{array}{c}\text { Contribution: } \\
\text { ratification }\end{array}$ & $\begin{array}{c}\text { Request: for } \\
\text { further infor- } \\
\text { mation }\end{array}$ & $\begin{array}{c}\text { Request: } \\
\text { to prompt } \\
\text { exploration }\end{array}$ & $\begin{array}{c}\text { Request: } \\
\text { directing to- } \\
\text { wards a new } \\
\text { register }\end{array}$ & $\begin{array}{c}\text { Contribution: } \\
\text { submission } \\
\text { deduction }\end{array}$ & \\
\hline 18 & 21 & 7 & 26 & 4 & 13 & 89 \\
\hline
\end{tabular}

\section{Interlocutory dimension: conversational chains}

The analysis of the pupils' speech events led us to fully dissociate the sequence P2.S1, from the sequences P2.S2 and P2.S3.

\section{Sequence P2.S1}

During this sequence, the pupils produced interventions that provided information that directly answered the question given. The use of sharing was: "making friends", "not fighting", "to have everything, nearly everything", etc. The answers were additionally illustrated using counterfactual examples (e.g. "it's good to share 'cos 'cos how // like that well a boy's:: sister:: well he / \# she's got the she's got half the pack of paper and the other half of the pack of paper \# and:: when they've got a box uh for both of them with felt tips and crayons"). These counterfactual examples were marked in the discourse by pronouns and indefinite articles (you, a sister and a brother, someone else, etc.).

The pupils entered an argumentative process where the aim was to find arguments that justified the proposition that it is good to share.

This process took the following form:

- Proposition (it's good to share)

- Because: Argument (argument response to "what use is sharing")

- Illustration (using a counterfactual example placed either before or after the argument).

We could also see that an argument proffered at a particular time point in a sequence, whatever its status, was often taken up again by other pupils and explored, explicitated, expanded or used as a premise. For example, during this period, one argument was: (it's good to share because) "you can make uh friends". In the subsequent CLs, this argument was reused: (it's good to share because ...)

- "... after the others uh they're our friends and we're friends ..." (rewording and explicitation of the initial argument)

- "... after we make lots of friends ..." (completion of the rewording of the initial argument)

- "... they won't fight, they'll be able to get on with doing what they want ..." (an implication having the initial argument as premise). 
Phase 1. Formulation of the task

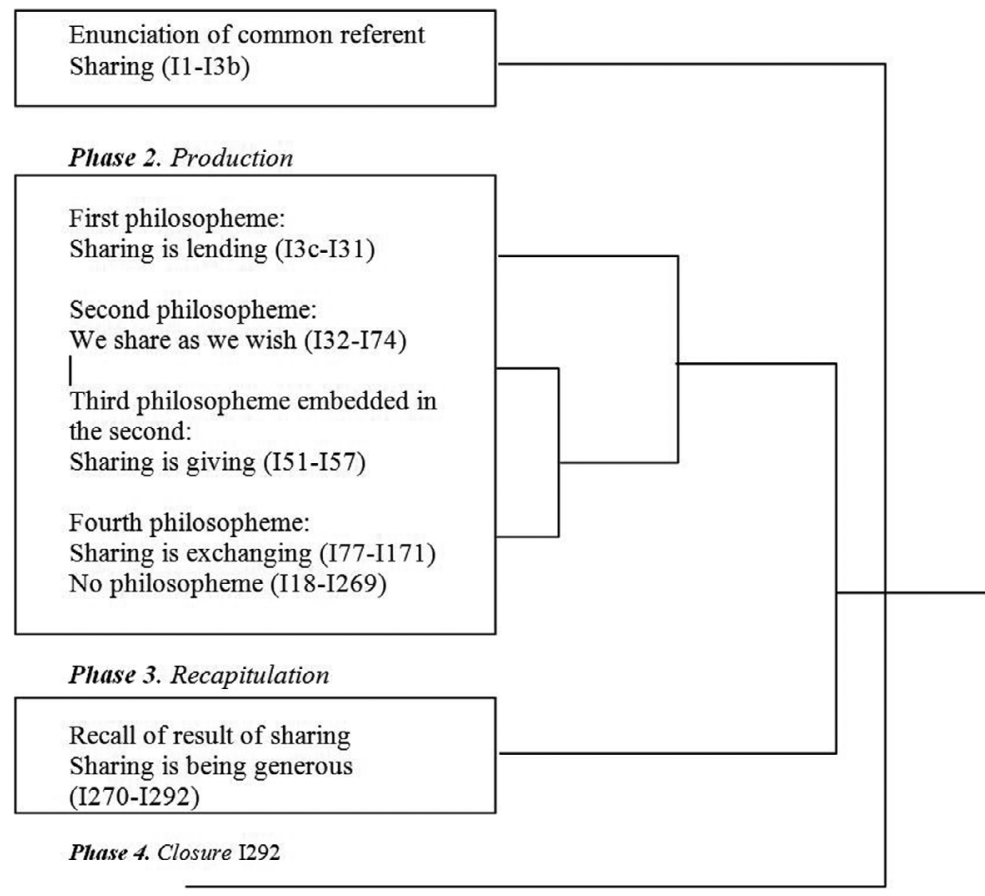

Figure 7. Instances of collective reasoning in chronological order.

Table 4. Occurrence of referents, ideas, concepts, stages and collective reasoning.

\begin{tabular}{|c|c|c|c|c|c|}
\hline \multirow[t]{2}{*}{ Localisation } & \multicolumn{2}{|c|}{ Thematic content } & \multicolumn{3}{|c|}{ Philosophical aspects } \\
\hline & Referent & Ideas & Concepts & Stages & Collective reasoning \\
\hline Phase 1 & 1 & & & & \\
\hline Phase 2 I3-I31 & 1 & 8 & 1 & 2 & 1 \\
\hline Phases 2 and 3132-174 & 1 & 7 & 2 & 2 & 2 \\
\hline Phases 2 and 3174-1269 & 1 & 18 & 1 & 1 & 1 \\
\hline Phase 3 I275-|291 & - & - & - & - & - \\
\hline Phase 4 I192 & - & - & - & - & - \\
\hline Total & 4 & 33 & 4 & 5 & 4 \\
\hline
\end{tabular}

Hence, the pupils listened to their classmates, integrated their arguments and succeeded in using them as components to be reworded, completed, explored or exploited as a premise.

This results in hierarchical relations among CLs (Figure 5). The ascending structure reveals that what was produced at a particular time formed a premise for subsequent productions. This shows that the dynamics of the collective activity during this phase depended in large part on what had first been produced and how it had been dealt with.

During this period, the teacher intervened essentially to allot STs. We note that four responding interactions were addressed to pupils in particular. The function of these elicitations is given in Table 2 .

The argumentative activity required to answer the question asked was exerted by the pupils.

\section{Sequences P2.S2 and P2.S3}

The pupils generally started their interventions by recalling factual instances that exemplified sharing situations of varying difficulty (out of the 29 CLs produced, 24 began with a factual example, 
Table 5. Content of referents, ideas, concepts, stages and collective reasoning.

\begin{tabular}{|c|c|c|c|c|c|}
\hline \multirow[b]{2}{*}{ Localisation } & \multicolumn{2}{|c|}{ Thematic content } & \multicolumn{3}{|c|}{ Underlying philosophical aspects } \\
\hline & $\begin{array}{l}\text { Common } \\
\text { referent }\end{array}$ & Idea & Concept & Stage & Collective reasoning \\
\hline $\begin{array}{l}\text { Phase } 1 \text { formula- } \\
\text { tion of the task }\end{array}$ & Sharing & & Not defined & none & none \\
\hline $\begin{array}{l}\text { Phase } 2 \text { produc- } \\
\text { tion }\end{array}$ & Sharing & $\begin{array}{l}\text { Sharing = good } \\
\text { (appreciative modal- } \\
\text { ity); equality, make } \\
\text { friends (consequenc- } \\
\text { es/result); we should } \\
\text { share (deontic } \\
\text { modality deontic, } \\
\text { obligation); avoid } \\
\text { fights, be polite, be } \\
\text { kind (result) }\end{array}$ & & $\begin{array}{l}\text { Axiological type: } \\
\text { It's good (14) }\end{array}$ & $\begin{array}{l}\text { Sharing is lend- } \\
\text { ing, lending in a } \\
\text { timescale (lending } \\
\text { has a beginning and } \\
\text { an end), Illustration } \\
\text { and persistence of } \\
\text { good behaviour in } \\
\text { the sense of human } \\
\text { behaviour as experi- } \\
\text { enced }\end{array}$ \\
\hline $\begin{array}{l}\text { Philosopheme } 1 \\
\text { sequence } 13-131\end{array}$ & & & Loan (I29) & $\begin{array}{l}\text { Deontic type: We } \\
\text { should (I10) }\end{array}$ & Perception of a reality \\
\hline $\begin{array}{l}\text { Philosopheme } \\
2 \text { sequence } 2 \\
\text { 132-174 }\end{array}$ & $\begin{array}{l}\text { Sharing-lend- } \\
\text { ing }\end{array}$ & $\begin{array}{l}\text { "I share with him/ } \\
\text { her" (appropriation } \\
\text { of concept: lending) }\end{array}$ & $\begin{array}{l}\text { Wish to share } \\
132-174\end{array}$ & $\begin{array}{l}\text { I share with him/ } \\
\text { her }\end{array}$ & $\begin{array}{l}\text { Sharing is giving - } \\
\text { give a part: the con- } \\
\text { sequence may be that } \\
\text { we lose something }\end{array}$ \\
\hline $\begin{array}{l}\text { Philosopheme } \\
3 \text { sequence } \\
151-157\end{array}$ & & $\begin{array}{l}\text { If we don't want to } \\
\text { give, then we lend }\end{array}$ & Gift (I35) & Volitional type & $\begin{array}{l}\text { Perception of a reality } \\
\text { that is not the same } \\
\text { for everyone: we } \\
\text { share as we wish, } \\
\text { sometimes we don't } \\
\text { want to share, we can } \\
\text { opt for not sharing }\end{array}$ \\
\hline \multirow[t]{2}{*}{$\begin{array}{l}\text { Philosopheme } \\
4 \text { sequence } \\
\text { 174-1269 }\end{array}$} & Sharing-wish & $\begin{array}{l}\text { Sharing only if the } \\
\text { others share too. If } \\
\text { we share, the others } \\
\text { share too (condi- } \\
\text { tions of sharing). }\end{array}$ & $\begin{array}{l}\text { Exchange } \\
(1171)\end{array}$ & $\begin{array}{l}\text { Casuistic type } \\
\text { Share only if } \\
\text { others share too } \\
\text { (I77) }\end{array}$ & $\begin{array}{l}\text { Sharing is exchang- } \\
\text { ing: the consequence } \\
\text { is reciprocal sharing, } \\
\text { and conditions asso- } \\
\text { ciated with sharing. } \\
\text { Glimpse of a difficulty. }\end{array}$ \\
\hline & & $\begin{array}{l}\text { Return to examples: } \\
\text { exchange money, } \\
\text { give money, } \\
\text { share = have more } \\
\text { fun, give to please; } \\
\text { exchange in } \\
\text { games; share = be } \\
\text { happy (result) } \\
\text { No philosophy }\end{array}$ & & & \\
\hline $\begin{array}{l}\text { Phase } 3 \text { recapitu- } \\
\text { lation sequence. } \\
\text { 1270- } 1292\end{array}$ & - & $\begin{array}{l}\text { No ideas considered } \\
\text { as philosophical - } \\
\text { return to previous } \\
\text { examples: the use of } \\
\text { sharing is to do lots } \\
\text { of things with other } \\
\text { people }\end{array}$ & & & $\begin{array}{l}\text { Conclusion. Sharing is } \\
\text { being generous }\end{array}$ \\
\hline $\begin{array}{l}\text { Phase 4. Closure } \\
\text { intervention } \\
\text { I } 292\end{array}$ & - & $\begin{array}{l}\text { No ideas considered } \\
\text { as philosophical, clo- } \\
\text { sure by the teacher }\end{array}$ & & & \\
\hline
\end{tabular}

and only 5 with an argument). The way in which the $\mathrm{CL}$ was initiated tended to show that generally they no longer placed their utterances in an argumentative sequence intended to justify the thesis whereby it is good to share, but more often in a narrative sequence, where they sought to relate their sharing experience.

The productions were less constrained by CLs that had just been produced - even if the examples related could activate memories of situations in the others - resulting in intersequence relations that were most often linear (Figure 6). 
The CLs thus most generally occupied the same position in the phase structure; they formed responses to the initial question as interpreted by the pupils, here: "report factual examples of sharing in which you took part". Whatever the case, we note that arguments were produced even when a CL was launched by an example. Generally, these arguments were elicited by responding interventions made by the teacher when she invited the pupils to draw lessons and general rules from the experience they had just recounted. These elicitations given in Table 3 were intended to guide, assist and explore. The responding interventions, which were prompts - a prompt being a subordinate intervention whose subject is the interlocutor's discourse (Blanchet \& Gotman, 2005) - were much more often present than in phase 1 , and significantly so.

\section{Cognitive dimension}

Figure 7 shows where the instances of collective reasoning are located.

In Table 4, we set out the materials (referents, ideas, concepts and stages) that contributed to and helped the emergence of collective reasoning and its occurrence. The content of these materials is detailed in Table 5.

The common referent, announced in phase 1, was not processed in the same way by all the interlocutors: this processing formed the next production phase. Here, a conceptual analysis caused us to divide one of the instances of collective reasoning into two conceptual sequences (I32-174, distinct from 151-157). Deduced from the thematic orientation, which enabled us to delimit the progression of the referential type, the interpretation of the underlying philosophical aspects produced four instances of collective reasoning extracted from the corpus: sharing is (i) lending, (ii) giving, (iii) exchanging, in the production phase, and (iv) being generous, which emerged in the operational phase of recapitulation.

During the production phase, the pupils managed to conceptualise first that sharing is a morally good action, which they illustrated with counterfactual examples: a certain reality was gradually perceived to be in play (we lend). A first instance of collective reasoning thus emerged: "sharing is lending".

The pupils, by exploring the theme of the loan, then transformed an unequivocal, moralising reality by an experience of diversity. In this process, only certain ideas led on to an exploration of sharing as a gift. But it was a prior movement, conceptualising the wish to share, that allowed the complete development of the collective reasoning: sharing is giving. It was access to the concept of gift that then made the situation complex and difficult, where the conditions, reciprocity and consequences complexified the initial doxa. Also, we saw the casuistic passage from one stated case to another, which essentially enabled the pupils to work out a philosophical reflexivity by exploiting the concept of exchange. The philosophical reasoning was constructed through successive stages where different conceptual fields were explored: Ioan (I29), gift (I35) and exchange (I171). The movement from the field of the gift (second instance of collective reasoning) led the pupils to escape from the single doxa introduced in the early speech events concerning the loan, which was trapped in its axiology (it's good) or deontology (we should), preventing any possibility for the exploration of the first instance of collective reasoning. The construction of the third instance of collective reasoning was marked by "if ... we", "Sharing is exchanging". It was composed essentially of examples; the usefulness of these could be debatable, as the reasoning was making no further philosophical progress, unless these examples can be considered as embodying new ideas. At this stage in the discussion, the pupils were actually replaying their earlier ideas on the diversity of personally experienced situations of happy exchange: to please, play, be happy, get something, have more fun, etc. The last instance of collective reasoning, "Sharing is being generous", then emerged in the operating phase of recapitulation, as a sum or possible axiological adjustment (repositioning on the doxa, it's good). The fact that the discussion ended rapidly, moving on to the closure phase, prevents us seeing whether the pupils would have taken their reasoning further. In the operating phase of production, the pupils' argumentation led them through four conceptual stages (loan/wish/gift/exchange), clarified or sometimes supported by situations in their daily lives, which they thus went on to examine. 


\section{Discussion}

\section{Results that enhance each other}

Consideration of the results obtained for each of the dimensions produces an understanding of the activity in its complexity and processuality. By proceeding in this way, we can make the following statements about the activity produced during the CPI taken as an example.

The discussion comprised several decisive functional sequences, which lie at the heart of the deployment of thought activity.

- The first sequence (P2.S1) followed the starting question. It consisted for the pupils in finding answers to the question "what use is sharing?" The CLs produced in this sequence displayed a hierarchical structure marking the fact that the pupils exploited the other speakers' productions in their own discourse: they reworded them, supported them, explicitated them and illustrated them with counterfactual examples. Essentially, they exploited doxa and testimony as a resource. They thus jointly produced a co-constructed, collective answer to the question "why is it good to share?"The modalities, both axiological (it's good to) and deontic (we should) that characterise this sequence reveal that they addressed the subject of "sharing" in its moral dimension, and went on to conceptualise sharing as a morally good action. This sequence was marked by the emergence of the first instance of collective reasoning, which served almost as a starting definition: sharing is lending. The teacher intervened little in the course of the CLs composing this sequence.

- The next sequences (P2.S2 and P2.S3) were initiated by the teacher, who communicated implicitly, and then more explicitly, that she wanted to hear about situations of difficult sharing involving the pupils. In P2.S2, the pupils, who had evidently not yet understood the teacher's intention, reported factual examples of sharing in which they were involved. In P2.S3, they recalled factual examples of sharing, non-sharing and difficulties met in sharing. In these two sequences, the CLs were more linearly related: the pupils no longer exploited their classmates' productions so much, although we note some stances in relation to others (I agree with so-and-so). We saw new discursive modalities appearing: volitional and aspectual. Through the recalled examples, the pupils transformed the unequivocal moralising reality developed in P2.S1 by an experience of diversity: through these examples, they were able to escape from the single doxa proffered in P2.S1 which remained trapped in a positive axiology ("it's good") or a single deontological orientation ("we should"). These examples impelled by the teacher led the pupils to examine new conceptual fields, that of giving and of exchanging, which formed stages for a broader conceptual deployment. During these two sequences, the pupils, helped more by the teacher (via her responding interventions through which she guided and assisted them, for example, to bring them to complete their problematised narrations), revisited their earlier ideas. These sequences heralded the emergence of two new instances of collective reasoning, in the sense of complete reasoning: "sharing is giving" or "sharing is exchanging".

- The recapitulation phase initiated by the teacher - a phase that may appear, from a cursory glance at the corpus, to offer nothing further since it is supposed to recapitulate what has already been said was, however, the time when a new, last instance of collective reasoning emerged: "Sharing is being generous", which could no doubt have led on to a new discursive phase. The ergonomic, semantic and conversational breakdown of the activity, extended by a philosophical study, shows that although an oral activity may cease, thought does not. Despite the teacher's pedagogical intention to wind up the debate, the collective conceptualisation at work continued beyond the discussion proper.

\section{Surprises that find explanations}

Some results were at first sight surprising, but findings from other dimensions of the activity yielded explanations. 
For example, the functional analysis of the activity (functional dimension) revealed two phase types: phases with an argumentative purpose and phases with a narrative purpose. The analysis of linkages between CLs (interlocutory dimension) revealed that these were linear in the narrative phases and hierarchical in the argumentative phases. Assuming with Auriac-Slusarczyk and Fiema (2013) that collective reasoning in CPI requires restatement of the referent and addition of arguments, and that this type of work must be seen through hierarchical linkages between components (one component used as premise in reasoning resulting in a hierarchical relation between components), we expected the argumentative phase marked by hierarchical linkages between CLs to be more likely to produce collective reasoning than narrative phases marked by linear linkages of CLs.

However, a study of the cognitive dimension of the activity revealed that only one instance of collective reasoning emerged in the argumentative phase against three in the narrative phases. This unexpected finding can be explained in the light of the results from the linguistic analysis (discursive dimension).

Thus, we can see that the examples chosen by the pupils formed the material in which referential contributions to the concept took shape. The work of conceptualisation was helped by the teacher's prompting. The discursive modalities and cognitive resources mobilised by the pupils to comment on and describe the examples they reported contributed to the collective conceptualisation. The teacher asking the pupils to bring up examples of sharing or non-sharing might have been expected to cause a gradual drift away from the initial question. Yet, it turns out that this apparent deviation from the task allowed collective reasoning to emerge.

Deviation fostered conceptualisation. Both the teacher and the pupils worked and advanced cognitively.

In CPI, if we take this example as valid, there is one aspect of conceptualisation that the pupils build from their cultural/experiential knowledge and the productions of others (P2.S1), and another aspect of conceptualisation (P2.S2 and P2.S3) that takes shape once the interactional space, mapped in particular by the localisation of the $\mathrm{CLs}$, has become a field of deployment for a variety of recalled examples, supported by help from the teacher.

\section{Conclusion}

Our purpose was to present a theoretical and methodological framework to describe what occurs during a complex activity taking place in and through speech interactions, and show its applicability using an example.

From our viewpoint, instances of communication are seen as the manifest part of the activity, and are considered as a way to gain access to the activity (at least in part). They are considered as comprising processes of various orders that support the activity: we have analysed them accordingly.

The framework is built on a paradigm that holds for all the dimensions of the activity addressed. This paradigm, in supporting each of the dimensions, lends consistency to our multiple framework. It ensures compatibility among the different forms of analysis, and allows crossing of the results obtained. The choice of the constructivist and interactionist paradigm is essential. It elicited a sequential approach to speech, highlighting interactional and co-constructional processes able to characterise the activity studied. Here, our investigation showed how collective reasoning, considered as reasoned thought movement, is the product of a contextualised collective exercise. It is associated not only with a theme and a shared referent, but also at the same time with a logical, creative collective reasoning exercise.

The framework allows the activity to be approached at a global level, centred on its communicational and functional dimensions; at a more local level, the productions were approached in their discursive dimension as semiotic tools, or more precisely as "acted speech events", to which we could linguistically assign a pragmatic aim, a thematic content and semantic properties. The study, which uses a dialogical approach to discourse, focused on conversational chains, and aimed to identify the resources exploited by the protagonists and discern to what extent the discourse was co-constructed. 
This framework makes no claim to cover all the dimensions of the activity. For example, we chose not to address the relational dimension of the activity (place relations, proximity of actors, or the co-constructed communicational contract). Here, we chose to focus on the cognitive dimension of this activity (how collective reasoning is created). We therefore retained only those other dimensions liable to contribute to an understanding of this dimension.

Also, some dimensions of the framework we propose must be refined and detailed according to the nature of the activity being analysed. The nature of the activity has, in particular, an impact on the concepts drawn on to address certain dimensions. For example, the concept of $\mathrm{CL}$ (communicative dimension) was used to take account of the distributive specificity of language productions in the class context; similarly, the concepts of referent, idea, stage and argument (cognitive dimension) were used to explain the processual emergence of collective reasoning.

Hence, although the framework proposed aims to address the activities that take form in language interactions, it must nevertheless be adapted to the nature of the activity being addressed and to the goals of the researchers. For example, if it is used to study activities that take form in dyadic interactions, then the study of the distribution based on communication networks is no longer relevant. By contrast, reference, for example, to the work of Sacks, Schegloff and Jefferson (1978) for a fine study of speech turn-taking might be useful. If researchers were interested in more conventional school activities, where, for example, explicative processes were dominant, then conceptual input could be taken for example from Baker (2000).

Hence, our framework, which can be extended according to the nature of the activity studied and researchers' aims, allows the description of collective activities that take place in speech interactions. The use of such a framework in a study thus lends researchers a useful resource to obtain a first glimpse of the activity in all its complexity. This resource can then be enriched by collecting other informative data, in view of the intentional character of all human interaction and given that the intentionality is not materialised either systematically or regularly in language productions (Saint-Dizier de Almeida \& Agnoletti, 2010), for example, the aims, purposes and values of the protagonists; useful additional data can be obtained, for example, using an explicitation interview (Vinatier, 2012). These elements allow a deeper analysis. It would then be possible to undertake explicative investigations. Thus, professionals, according to their sector, rather than obtain a logical explanation or overview of the interactions in terms of what they already know a priori about the practices, could derive from a study of discourse in all its complexity, such as we propose, elements that measure the importance of what is brought out. For example, in a Vygotskian view, we could, in the educational field, seek to explain from such results how the interactions provide material for the acquisition process (Vygotsky, 1978); or in Engeström's perspective, try to gain a better understanding of how the collective format acts on the structuring of the activity (Cole \& Engeström, 1993). In each case, explanation would be extending the study of speech interactions and not the reverse. We thus consider that we have shown how the methodological conditions of a study of the social aptitudes of persons to interact condition how we understand the capacity of those persons to produce (historically and culturally) interactions that are structured and hence structuring. Centring on a CPI that does not restrict in advance what can be said, linked to the fact that our CPI example concerns young pupils whose reasoning is a priori fairly simple, suggests that our approach may help researchers in education take full measure of the complexity of human language activity.

\section{Notes}

1. The discussion is excerpted from the corpus Philosophèmes collected by Emmanuèle Auriac-Slusarczyk in the course of research in the ACTé Laboratory with the support of the MSH, Clermont-Ferrand, as part of the pluridisciplinary project DIASIRE (2009). It is exploited in the framework of the Auverge Regional Structural Project (2011-2014). Associated references: Auriac-Slusarczyk and Blasco-Dulbecco (2010) and Auriac-Slusarczyk and Fraczak (2011).

2. This type of discussion at primary school, which in English-speaking countries has been termed "philosophy for children" (P4C), or more recently "collaborative philosophical inquiry" (CPI) (Millett \& Tapper, 2012), emerged in the USA in the 1980s through the initiative of Matthew Lipman (Leleux, 2005; Lipman, Sharp, \& Oscanyan, 1980). 
3. Translated into French as raisonnabilité (see Auriac-Slusarczyk \& Fiema, 2013). The term "reasonability" is also used in English.

4. A synthesis on the question of modality can be found, for example, in Kerbrat-Orecchioni (1980) and Le Querler (1996).

5. The emergence and resolution of this misunderstanding are studied in Saint-Dizier de Almeida (2013).

\section{Funding}

This work was supported by the Lorraine-MSH and Clermont-Fd-MSH.

\section{Notes on contributors}

Valérie Saint-Dizier de Almeida (PhD) is a teacher-researcher in social psychology at Lorraine University (France). Her research takes a pragmatic and dialogical approach to activities, particularly work-related ones, that are expressed through natural language, from both a fundamental and applied perspective.

Jean-Marc Colletta is a professor in Linguistics at Grenoble Alpes University (France). He is a member of the LIDILEM (Linguistics and Language Teaching) Lab. His research interests stand at the crossroad of language acquisition studies, multimodality and gesture studies and discourse pramatics.

Emmanuèle Auriac-Slusarczyk (PhD) is a teacher-researcher in social and educational psychology at Clermont Ferrand University (France). Her research focus on oral discussion and/or written composition conduced at school, through pragmatic approaches, to study reflexive and cognitive processes, underlined verbal agencements.

Antonietta Specogna (PhD) is a teacher-researcher in social psychology at Lorraine University (France). Her research takes a pragmatic and dialogical approach to activities. Her works mainly evolved in school situations to observe and analyse teacher practices and construction of the learnings of the pupils. That is expressed in ordinary situations and through natural language.

Jean-Pascal Simon (PhD) is a teacher-researcher in linguistic and didactic at Grenoble-Alpes University (France). His research is characterised by a double anchor: sociolinguistics as context and the language sciences for the description of interactions in teaching and learning.

Gabriela Fiema's (PhD student supervised by Emmanuèle Auriac-Slusarczyk at Clermont Ferrand University, France) research focus on collaborative philosophical inquiry through pragmatic approaches, to study reflexive and cognitive processes, underlined verbal agencements.

Christophe Luxembourger (PhD) is a teacher-researcher in psychology at Lorraine University (France). His research focuses on the analysis of linguistic interactions and in particular the conditions of emergence of the children's critical thinking.

\section{References}

Adam, J.-M. (1999). Linguistique textuelle. Des genres de discours aux textes [Text linguistics. From discourse genres to texts]. Paris: Nathan.

Auguet, G. (2003). La Discussion à Visée Philosophique aux cycles 2 et 3; un genre scolaire nouveau en voie d'institution ? Thèse de Doctorat 3ème cycle [Cooperative Philosophical Inquiry in primary school: a new kind of classwork undergoing institutionalization]. Montpellier: Université P. Valéry.

Auriac, E. (2007). Effet de discussions à visée philosophique sur le processus de génération d'idées [Effect of Cooperative Philosophical Inquiry on how ideas are generated]. Enfance, 59, 356-370.

Auriac-Slusarczyk, E., \& Daniel, M.-F. (2009). Apprendre à dialoguer avec des élèves: le cas des dialogues philosophiques [Learning to dialogue with pupils: The case of Cooperative Philosophical Inquiries]. Psychologie de l'Interaction, 25-26, 155-196.

Auriac-Slusarczyk, E., Adami, J., \& Daniel, M. F. (2011). Tester les prédispositions à l'esprit critique au primaire [Testing predispositions for critical thinking in primary school]. Psychologie \& Education, 1, 55-80.

Auriac-Slusarczyk, E., \& Blasco-Dulbecco, M. (2010). Subvention en réponse à l'appel à projet interdisciplinaire de la M.S.H. de Clermont Fd., rattachée à I'Université Blaise Pascal (U.B.P.) engageant le laboratoire P.A.E.D.I et le Laboratoire L.R.L., P.R.E.S. Clermont Université. (24 mois) "DiaSiRé: Dialogue, Signification \& réflexivité" [Funding in response to call for interdisciplinary projects by the Clermont-Ferrand research center (MSH) attached to Blaise Pascal University (UBP) involving the PAEDI and LRL research laboratories, and the Clermont University PRES (24 months)]. Demande Acceptée pour la première année, mai 2010. Budget $6000 €$ [Application accepted for the first year, May 2010. Budget 6000 EUR]. 
Auriac-Peyronnet, E., \& Daniel, M.-F. (2002). The specifics of philosophical dialogue: A case study of pupils aged 11 and 12 Years. Thinking, 16, 23-31.

Auriac-Slusarczyk, E., \& Fraczak, L. (2011-2014). Porteur du Dépôt de la réponse sur appel d'offre dans le programme: projet structurant en SHS Etude des phénomènes interlocutifs dans les discussions citoyennes à visée philosophique pratiquées à l'école et au collège (Projet subventionné par la Région Auvergne. Convention 939.92-65731/19474. Accepté-Financé $571000 €$ (dont deux contrats doctoraux sur trois ans)) [Submitter of reply to call for bids in the programme: structural human and social science project on the study of interlocutory phenomena in Cooperative Philosophical Inquiry practiced at primary and secondary school. Project funded by the Auvergne Regional Authority, Agreement No. 939.9265731/19474. Funding granted: 571000 EUR (including two three-year PhD contracts)].

Auriac-Slusarczyk, E., \& Fiema, G. (2013). Raisonner et discuter: Définitions et principe d'étude pragmatique du corpus [Reasoning and discussing: Definitions and principle of pragmatic corpus study]. Cahiers du LRL, 5, 41-74.

Austin, J. L. (1970). Quand dire c'est faire [How to do things with words]. Paris: Seuil.

Baker, M. J. (2000). Explication, Argumentation et Négociation: analyse d'un corpus de dialogues en langue naturelle écrite dans le domaine de la médecine [Explanation, argumentation and negotiation: Analysis of a corpus of dialogues in natural written language in the field of medicine]. Psychologie de I'Interaction, 9, 179-210.

Bange, P. (1992). Analyse conversationnelle et théorie de l'action [Conversational analysis and action theory]. Paris: HatierDidier.

Berrendonner, A. (1990). Pour une macro-syntaxe [For a macrosyntax]. Travaux de Linguistique, 21, 25-36.

Blanchet, A., \& Gotman, A. (2005). L'enquête et ses méthodes: L'entretien [The interview and its methods: The interview]. Paris: Armand Colin.

Caillier, J. (2001). The 'language mastery' school of thought. In M. Tozzi (Ed.), L'éveil de la pensée réflexive à l'école primaire (pp. 61-68). Paris: Hachette.

Cappeau, P., \& Auriac-slusarczyk, E. (2013). Présentation du corpus Philosophèmes: choix et spécificités [Presentation of the Cooperative Philosophical Inquiry corpus: Choice and specific features]. Cahiers du LRL, 5, 11-40.

Cole, M., \& Engeström, Y. (1993). A cultural-historical approach to distributed cognition. In G. Salomon (Ed.), Distributed cognitions. Psychological and educational considerations (pp. 1-46). New York, NY: Cambridge University Press.

Colletta, J.-M. (2004). Le développement de la parole chez l'enfant. Corps, langage et cognition [The development of speech in the child. Body, language and cognition]. Hayen: Mardaga.

Colletta, J.-M. (2013). Arguments pour une approche paramétrique de l'acte et du texte [Arguments for a parametric approach to act and text]. In M. Barbazan (Ed.), Enonciation, texte, grammaire. De la linguistique à la didactique (pp. 85-105). Rennes: Presses Universitaires de Rennes.

Connac, S. (2002). Comparaison entre conseil coopératif et discussion philosophique [Comparison between cooperative council and Cooperative Philosophical Inquiry]. In M. Tozzi (Ed.). Nouvelles pratiques philosophiques en classe. Enjeux et démarches (pp. 51-55). Rennes: Publications du C.R.D.P. de Bretagne.

Connac, S. (2004). Discussions à visée philosophique et classes coopératives en zones d'éducation prioritaire [Comparison between cooperative council and Cooperative Philosophical Inquiry]. Thèse en Sciences de l'éducation. Université de Montpellier 3, Montpellier.

Daniel, M. F. (1997). La philosophie et les enfants. Le programme de Lipman et l'influence de Dewey [Philosophy and children. The Lipman programme and the influence of Dewey]. Paris: De Boeck Université.

Daniel, M. F. (2005). Pour l'apprentissage d'une pensée critique au primaire [For the learning of critical thinking in primary school]. Québec: Les Presses de l'Université du Québec.

Daniel, M.-F., \& Auriac, E. (2011). Philosophy, critical thinking and philosophy for children. Educational Philosophy and Theory, 43, 415-435.

De Almeida, J., \& Saint-Dizier De Almeida, V. (1998). Conception Assistée par le Dialogue: des interactions verbales aux règles de fonctionnement du pilote d'un multi-robot [Dialogue-Aided Design: From verbal interactions to working rules for a multirobot driver]. In K. Kostulski \& A. Trognon (Eds.), Distribution des savoirs et coordination de l'action dans les équipes de travail (pp. 159-182). Nancy: Presses Universitaires de Nancy.

Doise, W., Mugny, G., \& Perret-Clermont, A. N. (1975). Social interaction and the development of cognitive operations. European Journal of Social Psychology, 5, 367-383.

Fiema, G. (2014). Etude des mouvements de la pensée collective lors des ateliers philosophiques au primaire et au collège [Study of collective thought movements during philosophy workshops in primary and secondary schools]. Thèse en sciences de l'éducation. Université Plaise Pascal, Clermont-Ferrand.

Flament, C. (1965). Réseaux de communication et structures de groupe [Communication network and group structures]. Paris: Dunod.

François, F. (1980). Dialogue, discussion et argumentation au début de la scolarité [Dialogue, discussion and argumentation in early schooling]. Pratiques, 28, 83-94.

François, F. (1990). La communication inégale, Heurs et malheurs de l'interaction verbale [Uneven communication. The ups and downs of verbal interaction]. Paris: Delachaux et Niestlé.

François, F. (1993). Pratiques de l'oral [Oral language practice]. Paris: Nathan.

Golder, C. (1996). Le développement des discours argumentatifs [The development of argumentative discourse]. Neuchâtel: Delachaux et Niestlé. 
Higgins, S., Hall, E., Baumfield, V., \& Moseley, D. (2005). A meta-analysis of the impact of the implementation of thinking skills approaches on pupils, research evidence in education library. London: EPPI-Centre, Social Science Research Unit, Institute of Education, University of London. Retrieved from http://eppi.ioe.ac.uk/cms/Default.aspx?tabid=338

Kerbrat-Orecchioni, C. (1980). L'énonciation. De la subjectivité dans le langage [Utterance. On subjectivity in language]. Paris: Armand Colin.

Kerbrat-Orecchioni, C. (1990). Les interactions verbales, Tome 1 [Verbal interactions]. Paris: Armand Colin.

Kostulski, K., \& Trognon, A. (1998). Le domaine cognitif de l'interlocution: un exercice d'analyse interlocutoire d'une transmission orale dans une équipe paramédicale [The cognitive domain in interlocution: An exercise in interlocutory analysis of oral transmission in a team of paramedics]. In K. Kostulski \& A. Trognon (Eds.), Communications interactives dans les groupes de travail (pp. 59-101). Nancy: Presses Universitaires de Nancy.

Lalanne, A. (2002). Faire de la philosophie à l'école élémentaire [Philosophizing at infants school]. Paris: ESF.

Le Querler, N. (1996). Typologie des modalités [Typology of modalities]. Caen: Presses Universitaires de Caen.

Leleux, C. (Ed.). (2005). La philosophie pour enfants. Le modèle de Matthew Lipman en discussion [Philosophy for children. A discussion of the model of Matthew Lipman]. Bruxelles: De Boeck \& Larcier.

Lipman, M. (1995). A l'école de la pensée [At the school of thought]. Bruxelles: DeBoeck Université.

Lipman, M. (2005). Renforcer le raisonnement et le jugement par la philosophie [Strengthening reasoning and judgement through philosophy]. In C. Leleux (Ed.), La philosophie pour enfants. Le modèle de Matthew Lipman en discussion (pp. 11-24). Bruxelles: De Boeck Université.

Lipman, M., Sharp, A.-M., \& Oscanyan, F. S. (1980). Philosophy in the classroom. Philadelphia, PA:Temple University Press.

Marro-Clément, P., Trognon, A., \& Perret-Clermont, A. N. (1999). Interlocutory processes in a liquid conservation task. In M. Gilly, J. P. Roux, \& A. Trognon (Eds.), Apprendre dans l'interaction: analyse des médiations sémiotiques (pp. 163-180). Nancy: Presses Universitaires de Nancy.

Mead, G. H. (1934). Mind, self and society. Ed. C. W. Morris. Chicago, IL: University of Chicago Press.

Millett, S., \& Tapper, A. (2012). Benefits of collaborative philosophical inquiry in schools. Educational Philosophy and Theory, 44, 546-567.

Ministerial Council on Education, Employment,Training andYouth Affairs (MCEETYA). (2008). Melbourne declaration on education goals for young Australians. Retreived August 21, 2009, from (http://www.mceecdya.edu.au/verve/_resources/ National_Declaration_on_the_Educational_Goals_for_Young_Australians.pdf

Moeschler, J. (1985). Argumentation et conversation: éléments pour une analyse pragmatique du discours [Argumentation and conversation: Elements for a pragmatic analysis of discourse]. Genève: HATIER-CREDIF.

Mortier, F. (2005). Etudes d'évaluation: la méthode de Matthew Lipman comme moyen de développement [Evaluation studies: the method of Matthew Lipman as a means of development]. In C. Leleux (Ed.), La philosophie pour enfants. Le modèle de Matthew Lipman en discussion (pp. 47-69). Bruxelles: De Boeck Université.

Oléron, P. (1977). Le raisonnement [Reasoning]. Que sais-je?. Paris: PUF.

Piaget, J. (1976, ed. orig. 1923). Le langage et la pensée chez l'enfant [Language and thought in children]. Neuchâtel: Delachaux et Niestlé.

Plantin, C. (1990). Essais sur l'argumentation [Essays on reasoning]. Paris: Kimé.

Rispail, M. (Ed.). (2007). Apprendre à parler, apprendre à penser. Les ateliers de philosophie [Learning to speak, learning to think. Philosophy workshops]. Paris: Sceren, Nice: CRDP.

Roulet, E. (1999). La description de l'organisation du discours [Description of the organization of discourse]. Paris: Didier.

Roulet, E., Auchlin, A., Moeschler, J., Rubbattel, C., \& Schelling, M. (1985). L'articulation du discours en français contemporain [The articulation of discourse in contemporary French]. Berne: Peter Lang.

Sacks, H., Schegloff, E., \& Jefferson, G. (1978). A simplest systematics for the organization of turn-taking in conversation. In J. Schenkein (Ed.), Studies in the organization of conversational interaction (pp. 7-55). New York, NY: Academic Press.

Saint-Dizier de Almeida, V. (2013). L'activité sous l'angle de la psychologie ergonomique: analyse d'une discussion à visée philosophique [Activity from the viewpoint of ergonomic psychology: analysis of a Cooperative Philosophical Inquiry]. Cahiers du LRL, 5, 75-94.

Saint-Dizier de Almeida, V., \& Agnoletti, M.-F. (2010). How to pick up a stranger: Study of interlocutory processes in a flirtatious encounter. Journal of Pragmatics, 42, 1637-1646.

Saint-Dizier de Almeida, V., \& Trognon, A. (2000). Quelles techniques d'élicitation pour la conception des systèmes experts de deuxième génération [Which techniques of elicitation for the design of second-gereration expert systems?]. Connexions, $74,121-136$.

Schubauer-Leoni, M. L., Bell, N., \& Grossen, M. (1989). Problems in assessment of learning: The social construction of questions and answers in the scholastic context. International Journal of Educational Research, 13, 671-684.

Searle, J. R. (1982). Sens et expressions. Etudes de théorie des actes de langage [Meaning and expression. Studies of speech act theory]. Paris: Hermann.

Specogna, A. (2013). Enonciations d'élèves et tentative de construction collective de l'enseignante: regard de la pragmatique [Pupils' utterances and teachers' attempts at collective construction: The pragmatic viewpoint]. Cahiers du LRL, 5, 95-113.

Spigolon, G., \& Specogna, A. (2000). Compétences sociales et cognitives en construction: comment décrire la collaboration des interlocuteurs en séance de langage [Constructing social and cognitive skills: how to describe interlocutors in a language session]. Psychologie Française, 45, 209-218. 
Suchman, L. A. (1987). Plans and situated actions. The problem of human/machine communication. Cambridge: Cambridge University Press.

Topping, K. J., \& Trickey, S. (2007). Collaborative philosophical enquiry for school children: Cognitive effects at 10-12 years. British Journal of Educational Psychology, 77, 271-288.

Tozzi, M. (Ed.). (2007). Apprendre à philosopher par la discussion. Pourquoi? Comment? [Learning to philosophize through discussion. Why? How?] Bruxelles: DeBoeck \& Larcier.

Trognon, A. (1993). Eléments de rhétorique des débats: L'usage de la contradiction dans les débats politiques [Elements of debating rhetoric: The use of contradiction in political debates]. Verbum, 1-2-3, 251-264.

Trognon, A. (1999). Éléments d'analyse interlocutoire [Elements of interlocutionary analysis]. In M. Gilly, J. P. Roux, \& A. Trognon (Eds.), Apprendre dans l'interaction: analyse des médiations sémiotiques (pp. 69-94). Nancy: Presses Universitaires de Nancy.

Trognon, A., \& Batt, M. (2003). Representing the shift from inter-subjectivity to intra-subjectivity: An essay on interlocutory logic. L'Orientation scolaire et professionnelle, 32, 399-436.

Trognon, A., \& Brassac, C. (1992). L'enchaînement conversationnel [The conversational chain]. Cahiers de Linguistique Française, 13, 76-108.

Trognon, A., \& Kostulski, K. (1996). L'analyse de l'interaction en psychologie des groupes: Economie interne et dynamique des phénomènes groupaux [Analysis of interaction in group psychology: Internal economy and dynamics of group phenomena]. Connexions, 68, 73-117.

Trognon, A., \& Saint-Dizier, V. (1999). L'organisation conversationnelle des malentendus: Le cas d'un dialogue tutoriel [Conversational analysis of a misunderstanding: the case of a tutorial dialogue]. Journal of Pragmatics, 31, 787-815.

Trognon, A., Saint-Dizier de Almeida, V., \& Grossen, M. (1999). Résolution conjointe d'un problème arithmétique ou comment décrire des cognitions distribuées dans la conversation? [Joint solution of an arithmetic problem, or how to describe distributed cognitions in conversation]. In M. Gilly, J. P. Roux, \& A. Trognon (Eds.), Apprendre dans l'interaction: analyse des médiations sémiotiques (pp. 119-139). Nancy: Presses Universitaires de Nancy.

Usclat, P. (2008). La participation du maître à la Discussion à Visée Philosophique (DVP) et le statut de l'interlocuteur compétent : de la compréhension à l'intercompréhension [The teacher's participation in Cooperative Philosophical Inquiry (CPI) and the status of the competent interlocutor: From comprehension to intercomprehension]. Diotime, 36. Retrieved from http://www.educ-revues.fr/Diotime/affichagedocument.aspx?iddoc=32891\&pos=2

Vinatier, I. (2012). Réflexivité et développement professionnelle; Une orientation pour la formation [Reflexivity and occupational development. Guidance for training]. Toulouse: Octarès.

Vion, R. (1992). La communication verbale [Verbal communication]. Paris: Hachette Supérieur.

Vygotsky, L. S. (1978). Mind in Society. Cambridge, MA: Harvard University Press.

Williams, S. (1993). Evaluating the effects of philosophical enquiry in a secondary school. Derbyshire: Derbyshire County Council. 